\title{
Biogeochemistry of an Amazonian podzol-ferralsol soil system with white kaolin
}

\author{
Y. Lucas ${ }^{1}$, C. R. Montes ${ }^{2}$, S. Mounier ${ }^{1}$, M. Loustau Cazalet ${ }^{1}$, D. Ishida ${ }^{3,{ }^{*}}$, R. Achard ${ }^{1,{ }^{* *}}$, C. Garnier ${ }^{1}$, B. Coulomb ${ }^{4}$, \\ and A. J. Melfi ${ }^{5}$ \\ ${ }^{1}$ PROTEE, Université du Sud Toulon-Var, La Garde, Toulon, France \\ ${ }^{2}$ NUPEGEL, CENA, Universidade de São Paulo, Piracicaba, Brazil \\ ${ }^{3}$ NUPEGEL, IG, Universidade de São Paulo, São Paulo, Brazil \\ ${ }^{4}$ LCE-DMCM, LCP, Aix-Marseille Université, Marseille, France \\ ${ }^{5}$ NUPEGEL, ESALQ, Universidade de São Paulo, Piracicaba, Brazil \\ *now at: NUPEGEL, CENA, Universidade de São Paulo, Piracicaba, Brazil \\ ** now at: INERIS, Aix-en-Provence, France \\ Correspondence to: Y. Lucas (lucas@univ-tln.fr)
}

Received: 23 December 2011 - Published in Biogeosciences Discuss.: 28 February 2012

Revised: 14 August 2012 - Accepted: 28 August 2012 - Published: 28 September 2012

\begin{abstract}
The podzol-ferralsol soil systems, which cover great areas of Amazonia and other equatorial regions, are frequently associated with kaolin deposits and store and export large amounts of carbon. Although natural organic matter (NOM) plays a key role in their dynamics, little is known about their biogeochemistry. In order to assess the specific role of dissolved organic matter (DOM) on NOM storage in deep horizons and to determine possible relationships between kaolin formation and DOM properties, we studied the groundwater composition of a typical podzol-ferralsol soil catena from the Alto Rio Negro region, Brazil.

Groundwater was sampled using tension-free lysimeters placed according to soil morphology. DOC, $E_{\mathrm{H}}, \mathrm{pH}$, and dissolved $\mathrm{Si}, \mathrm{Al}^{3+}, \mathrm{Fe}^{2+}$, and $\mathrm{Fe}^{3+}$ were analyzed for all samples and values are given in a database. Quantification of other dissolved ions, small carboxylic acids and SUVA 254 index and acid-base microtitration was achieved on selected samples.

Part of the DOM produced by the hydromorphic podzols is directly exported to the blackwater streams; another part percolates at greater depth, and more than $90 \%$ of it adsorbs in the Bh-Bhs horizons, allowing carbon storage at depth. Humic substances are preferentially adsorbed with regard to small carboxylic compounds.

With regard to kaolin genesis, kaolinite precipitation is favored by $\mathrm{Al}$ release from NOM mineralization within the Bh-
\end{abstract}

Bhs and kaolin bleaching is ensured by iron reduction due to acidity and relatively low $E_{\mathrm{H}}$. Fe $\mathrm{Fe}^{2+}$ mobility can be related to small $E_{\mathrm{H}}$ variations and enhanced by the significant concentration of small carboxylic acids. The long-term result of these processes is the thickening of the kaolin, and it can be inferred that kaolin is likely to occur where active, giant podzols are close to a slope gradient sufficient enough to lower the deep water table.

\section{Introduction}

More than $18 \%$ of the Amazonian area is covered by podzolferralsol systems (RadamBrasil, 1978), which are characterized by the juxtaposition of podzols and ferralsols on the same landscape units (Lucas et al., 1984). Ferralsols are usual, climacic soils of equatorial areas where high weathering rates and long-time evolution allowed the leaching of all major elements except $\mathrm{Al}, \mathrm{Fe}$ and $\mathrm{Ti}$, the persistence of $\mathrm{Si}$ as kaolinite in the upper horizons being allowed by plant cycling (Lucas et al., 1993). The podzols appear and develop where dissolved organic matter (DOM) is able to percolate through soil horizons down to the rivers, allowing Al and $\mathrm{Fe}$ leaching and thus favoring the dissolution of clay and iron oxides (Lucas et al., 1996; Lundström et al., 2000; Nascimento et al., 2004). Once initiated, this process induces 
a positive feedback for $\mathrm{Al}$ and $\mathrm{Fe}$ leaching, resulting in a progressive replacement of the ferralsols by podzols, even where ferralsols are clayey. Large podzol areas constitute thus one end-member of equatorial soils and landscape evolution (Dubroeucq and Volkoff, 1998) (Fig. 1).

The podzol areas have the ability to release great amounts of dissolved organic carbon (DOC) (Leenheer, 1980; Chauvel et al., 1996; Benedetti et al., 2003; Patel-Sorrentino et al., 2007) in the draining waters, which flow afterwards to the sea through the river network. Considering the Amazon basin, they provide a tenth of the $0.13 \mathrm{PgC}$ annually exported to the sea (Tardy et al., 2009). They also can store large amounts of carbon in the upper and the deep Bh and Bhs horizons (Batjes et Dijkshoorn, 1999; Bernoux et al., 2002; Veillon and Soria-Solano, 1988; Nascimento et al., 2004). According to Montes et al. (2011), hydromorphic podzols can store $86.8 \pm 7.1 \mathrm{kgC} \mathrm{m}^{-2}$, and at least $13.6 \pm 1.1 \mathrm{PgC}$ is stored in Amazonian podzols. These soil systems therefore make a significant contribution to the $\mathrm{CO}_{2}$ cycle at the global scale, but the dynamics of DOM transfer and soil organic matter (SOM) accumulation is still poorly known.

Podzol-ferralsol systems are also frequently associated with kaolin deposits (Montes et al., 2007), which are geological or pedological formations rich in kaolinite-type clays. In the Amazon area, thick, white kaolin horizons (up to $10 \mathrm{~m}$ thick) were observed beneath ferralsol-podzol systems developed over sedimentary (Lucas et al., 1984; Chauvel et al., 1987; Costa and Moraes, 1998; Fritsch et al., 2009) as well as crystalline basement rocks (Dubroeucq and Volkoff, 1998; Montes et al., 2011), raising the question of the genetic relationships between podzolic processes and kaolin genesis in order to provide guidance for kaolin prospecting. Kaolin genesis is favored where weathering enhances quartz and $\mathrm{Fe}$-bearing mineral dissolution while maintaining kaolinite stability. As DOM issued from podzols favors the dissolution of all types of clay minerals because of $\mathrm{Al}$ complexation, how can podzolic processes favor kaolin genesis? Montes et al. (2007) hypothesized that the DOM transferred at depth by podzolic groundwater adsorbs within the Bh-Bhs horizon and that part of it is mineralized, which turns the acidic percolating water more reductive, favoring iron leaching and allowing bleaching of kaolin horizons. Such a hypothesis, however, needs to be assessed by studying $\mathrm{pH}, E_{\mathrm{H}}, \mathrm{DOM}$ and $\mathrm{Fe}$ and $\mathrm{Al}$ species in percolating groundwaters. Several detailed studies of the solid mineral and organic phases have already been conducted on Amazonian podzols (Bravard and Righi, 1991; Nascimento et al., 2004; Bardy et al., 2008; Fritsch et al., 2009), showing that horizon morphology and solid phase characteristics are very similar from one system to the other, but the properties or composition of the circulating solutions was only inferred from the properties of solid phases. Few works (Cornu et al., 1997, 1998; Nascimento et al., 2008) have focused on sampling and studying the percolation solutions, mainly because of difficulties of sampling groundwater in these re-

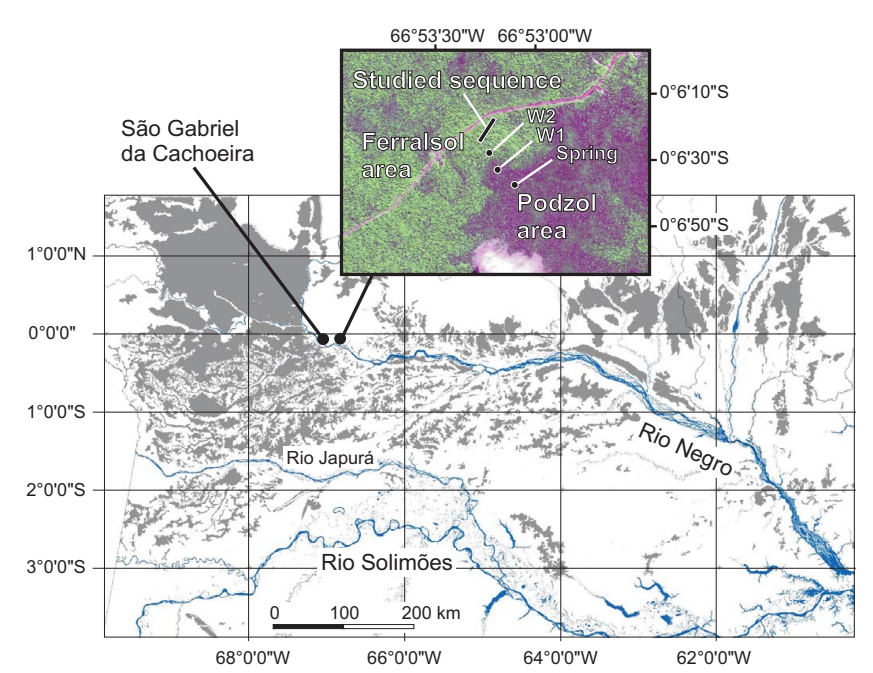

Fig. 1. Situation of the studied catena and extension of highly podzolic areas (in grey) in the Rio Negro basin. Compilation of highly podzolic areas was realized from digitalized soil maps of Amazonia (IBGE, 2009). The detailed view of the study area is issued from IKONOS imagery. The darker forested area corresponds to closed, low forest over hydromorphic podzols. W2 and W1 are sampling points outside the catena.

gions. More generally, except for the surface horizons, little is directly known about percolating soil solution in humid tropic soils.

In this context, the aim of the paper is two-fold, both related to natural OM dynamics. First, what is the specific role of DOM with regard to the soil system dynamics, particularly soil OM accumulation in deep horizons and OM transfer towards the river network? Second, is there a relationship between kaolin formation and OM properties, and, if so, will kaolin formation be favored at specific locations within the soil system? Such knowledge would help in predicting the possibility of kaolin ore from remote sensing. The answer to these questions has been sought by studying groundwater percolation in a podzol-ferralsol system whose morphology and mineralogy had been studied in previous work.

\section{Material and methods}

\subsection{Description of the study area}

The studied soil catena is situated near the São Gabriel da Cachoeira city, Amazonia State, Brazil, at $0^{\circ} 6^{\prime} 21^{\prime \prime} \mathrm{S}$ and $66^{\circ} 54^{\prime}$ $22^{\prime \prime} \mathrm{W}$ (Fig. 1), and was described in previous publications (Montes et al., 2007; Ishida, 2010). It was chosen amongst 11 similar catenas that have been studied on the same site, thereby ensuring its representativeness. It cuts the edge of a plateau where giant podzols developed from the plateau center at the expense of reddish yellow, low activity clay ferralsols, as described elsewhere (Lucas et al., 1988; Dubroeucq 
and Volkoff, 1998). It is related to a river network that enters the plateau by regressive erosion.

The climate is typically equatorial, with an annual rainfall around $3000 \mathrm{~mm}$, without a marked dry season and with a great interannual variability. Daily rainfall data were obtained from the airport station situated $6 \mathrm{~km}$ from the study area. The geological substratum is composed of crystalline rocks having composition varying between monzogranitic, syenogranitic and quartz-monzonitic (Dall' Agnol and Macambira, 1992). The vegetation over the ferralsols and over well-drained podzols is a typical lowland tropical evergreen forest and over the hydromorphic podzols a specific forest called campinarana and characterized by a high density of smaller trees (20-30 m). Such differences in vegetation are typical in podzol-ferralsol systems (Prance, 1978), and both forest type and soil characteristics result in high DOM differences between ferralsol and podzol groundwater (Bravard and Righi, 1991; McClain et al., 1997; Zanchi et al., 2011). In ferralsol areas, DOM adsorption and high decomposing rates account for low DOM concentrations in groundwater and streams (white or clear waters), with low $\mathrm{C} / \mathrm{N}$ ratio and aliphatic, poorly aromatic fulvic and humic acids (FA and HA). In podzol areas, the lack of DOM adsorption and low decomposing rates account for high DOM concentrations in groundwater and streams (black waters), with high $\mathrm{C} / \mathrm{N}$ ratio, poorly hydrolysable $\mathrm{N}$, poorly aliphatic and highly aromatic FA and HA. The soils were studied using a structural analysis approach (Boulet et al., 1982; Delarue et al., 2009). Macromorphological features were observed through hand auger boreholes and pit descriptions. Mineralogy was determined by X-ray diffraction on powder samples, diffuse reflectance spectroscopy and thermogravimetric analysis. Only the data necessary to understand the water geochemistry are given here; detailed methodology, mineralogy and geochemistry are given in Ishida (2010).

The soil catena (length $200 \mathrm{~m}$, difference in altitude $15 \mathrm{~m}$ ) is sketched in Fig. 2. Two main sets of horizons can be distinguished: (i) the horizons of the well-expressed podzols, at the upper part of the catena, and (ii) the oxic horizons colored by Fe-oxides on the slopes. Thick kaolin horizons were observed below both podzolic and oxic horizons. Mineralogical data are summarized in Table 1.

The podzols have a typical vertical succession of horizons: $\mathrm{O}, \mathrm{A} 1$, Es, Bh, Bhs. The organic $\mathrm{O}$ horizons are peat-like, with a thickness varying from a few centimeters to more than 50. The more water-logged the topsoil throughout the year, i.e. far from the plateau slopes, the thicker the O horizons are. The humic A1 horizons are well-developed; they consist of clean, white quartz sand and organic matter particles. The eluviated sandy Es horizons have thin (1-2 mm), dark grey micro-horizons colored by organic matter particles; they have traces of kaolinite and gibbsite and high porosity and hydraulic conductivity. The transition between Es horizons and the underlying kaolin shows the following vertical sequence: (1) $\mathrm{Bh}$ - the Es horizon turns progressively

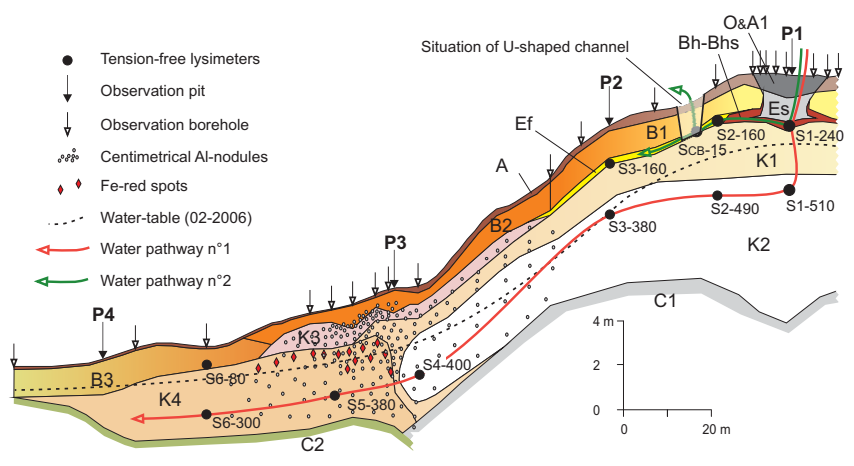

Fig. 2. View of the soil system along the catena. Capital letters of horizon names refer to FAO (1993). O: organic, peat-like horizon; A1: organic-rich, dark brown horizon; A: horizons brown-colored by organic matter; Es: podzolic eluviated horizons; B1: oxic B horizons varying from sandy upslope to sandy-clayey downslope; B2: oxic sandy-clay B horizons; B3: pseudogley B horizons; K: kaolin horizons; Bh-Bhs: horizons with organic matter and Al-Fe accumulation; Ef: non-podzolic leached horizon; $\mathrm{C} 1$ and $\mathrm{C} 2$ : saprolitic horizons. P1 to P4: situation of mineralogical data given in Table 1.

darker, due to an increase of organic matter content; (2) Bhs - there is an irregular, finger-like transition towards a hardened, sandy-clay horizon, brown-colored (10YR 5/2) (colors are given according to Munsell, 1990) with dark brown (7.5YR 5/6) features formed by organic matter and Fe-oxides accumulation in cracks and tubular pores; the gibbsite content is higher, and the quartz sand content diminishes quickly in depth, together with the increase of kaolinite, and the hydraulic conductivity turns lower. The kaolin K1 and K2 horizons consist mainly of kaolinite, with gibbsite content around $8 \%$ at the upper part of $\mathrm{K} 1$ and decreasing in depth to be lower than $2 \%$ at the lower part of K2 (Fig. 3). The upper part of the kaolin is a clayey, whitish material with some orangecolored coatings in tubular pores (K1 horizon). These coatings progressively diminish in depth, giving place to a homogeneous, white, clayey, butter-like material (K2 horizon). At depth, the $\mathrm{C} 1$ horizon is a silt-clay saprolite with muscovite and weathered feldspar.

Going downslope, podzolic horizons are replaced by oxic horizons colored by Fe-oxides: A horizons, on the upper part of the profiles; B1 horizons, which progressively change from sandy to sandy-clay in the downslope direction; B2 sandy-clay horizons; B3 horizons in the downslope position having water-logging features. Below the B1 horizon, a silty clay loam, pale yellow horizon with coarse quartz grains (Ef) was observed. It indicates a perched water table and is associated with U-shaped channels ( 2 to $4 \mathrm{~m}$ wide and 1 to $2 \mathrm{~m}$ depth) whose flat bottom is at the same altitude as the Ef horizon, the channels forming a hydrographical network on the slopes. In depth ,the thick kaolin horizons, the clayey K1 and $\mathrm{K} 2$ horizons extend downslope. The colors are yellow (10YR 8/6) and white (5Y 8/1 to $5 \mathrm{Y} 8 / 2$ ), for $\mathrm{K} 1$ and $\mathrm{K} 2$ horizons, respectively. A K3 horizon having some remaining 
Table 1. Minerals identified in the soil material. Pits and horizon are located on Fig. 2. A: anatase, M: muscovite, V: vermiculite, Mc: microcline, $\mathrm{Mg}$ : magnetite, I: illite, R: rutile, Go: goethite, $\mathrm{H}$ : hematite, $\varepsilon$ : very small amounts.

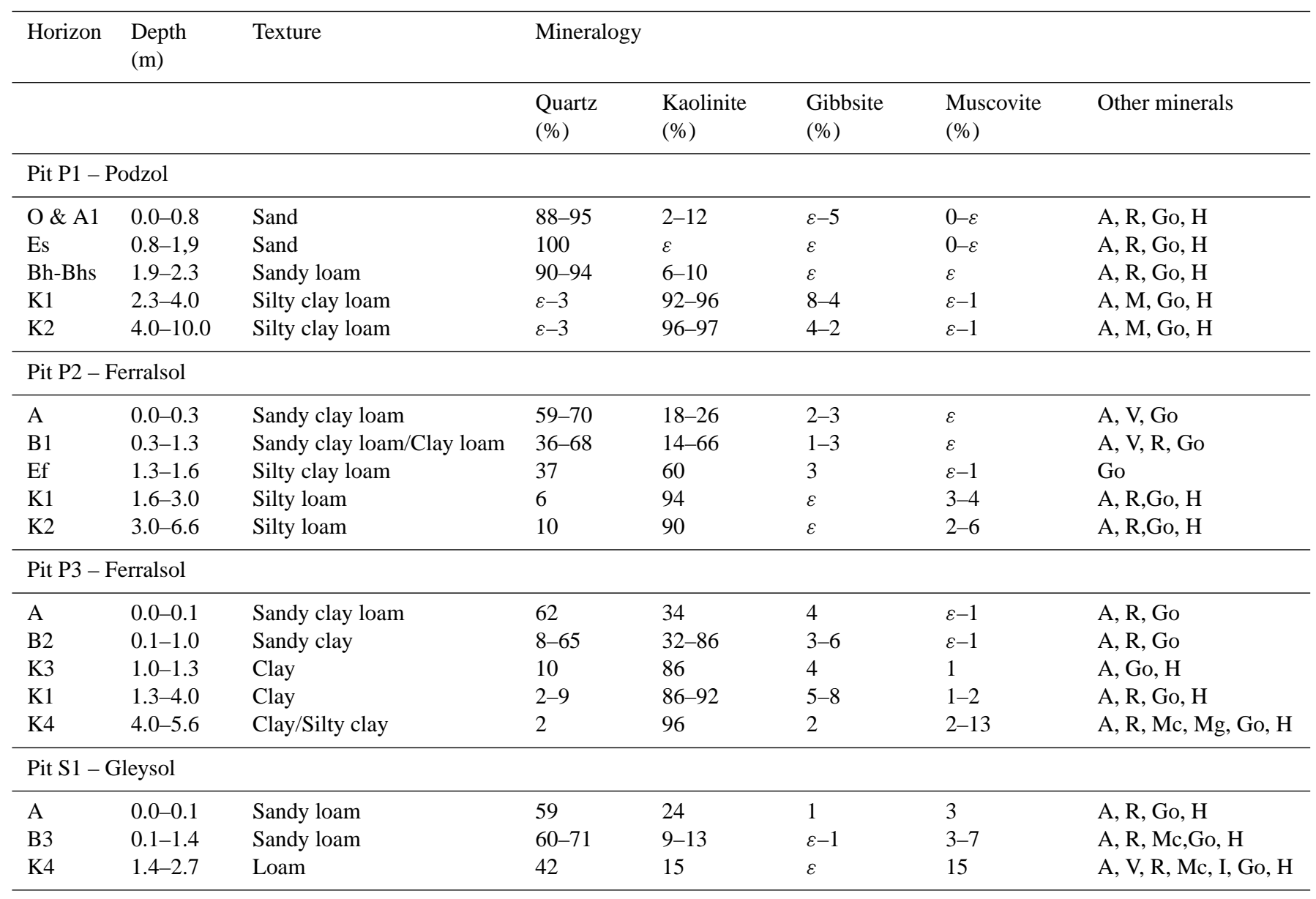

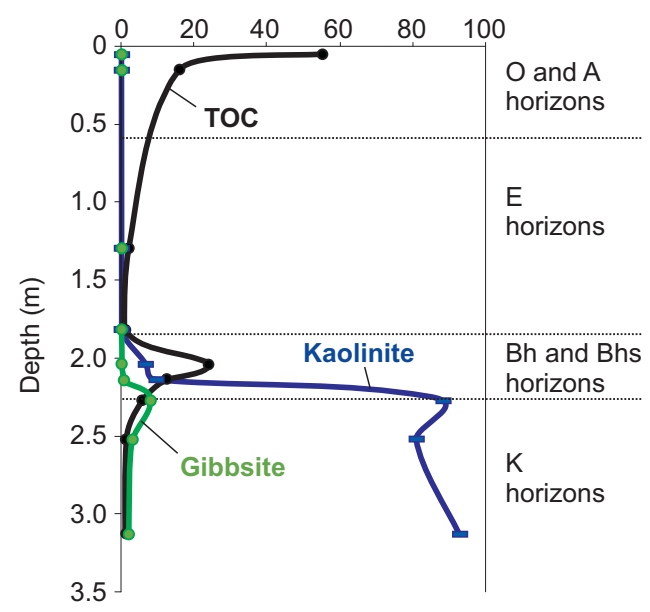

Fig. 3. Solid soil phase: kaolinite, gibbsite and total organic carbon (TOC) in the podzol from the upper part of the catena (Pit 1). Horizontal axis is in \% for kaolinite and gibbsite and in \%o for TOC. quartz grains and some red and yellow nodules appears at the mid-slope at the upper part of the kaolin body. Downslope, the $\mathrm{K} 1$ and $\mathrm{K} 2$ horizons give place to the $\mathrm{K} 4$ horizon characterized by more abundant unweathered muscovite and $\mathrm{Fe}$ red spots at its upper part. Gibbsitic nodules are located at the downslope half of the catena as indicated in the figure. In depth, $\mathrm{C} 1$ and $\mathrm{C} 2$ horizons are saprolitic horizons having many muscovite and weathered feldspar. At the lower part of the catena, the water table had the typical odor of sulphurs.

\subsection{Water sampling and analysis}

\subsubsection{Lysimeters}

It appeared unnecessary for the purpose of the present work to collect and analyze rain openfall, throughfall and stemflow. Such a study is difficult because of highly spatial variability under forest cover and had already been conducted in a similar podzol-ferralsol system throughout a whole year (Cornu et al., 1998). The results showed that the precipitation input was negligible with regard to mineral-solution 
equilibrium in soil horizons. Mean concentrations and standard deviation in openfall were $0.02 \pm 0.01,0.03 \pm 0.02$ and $0.04 \pm 0.02 \mathrm{mg} \mathrm{l}^{-1}$ for dissolved $\mathrm{Si}, \mathrm{Al}$ and $\mathrm{Fe}$, respectively; in throughfall, they were $0.08 \pm 0.04,0.06 \pm 0.04$ and $0.07 \pm 0.05 \mathrm{mgl}^{-1}$, respectively. Stemflow fluxes were insignificant.

Regarding groundwater, 13 zero-tension lysimeters were installed inside drilling holes at different depths, 2 points (W1-20 and W2-150) within the podzolic campinarana area (Fig. 1) and 11 points along the soil catena (Fig. 2). After installing the lysimeters, each drilling hole was tamped by filling with the previously extracted soil material at the corresponding depth. Each lysimeter was made of a $50 \mathrm{ml}$ polypropylene bottle bored with $5 \mathrm{~mm}$ diameter holes all around. A $2 \mathrm{~mm}$ diameter capillary PTFE tube was inserted through the bottle cap in order to permit extracting water from the topsoil with a manual vacuum pump. To prevent clogging of the capillary tube by soil particles, a cylindrical filter made of a SEFAR NITEX $64 \mu \mathrm{m}$ polyamide open mesh was put inside the bottle. All lysimeters were acid-washed prior to installation.

\subsubsection{Sampling points}

The studies already conducted on Amazonian podzolferralsol systems (see introduction) have shown that horizon morphologies and solid phase characteristics are very similar from one system to the other: soil age and high weathering rates have resulted in obliteration of most small-scale spatial variability due to parent rock heterogeneity. As in many old, deeply weathered soil covers, soil variations are spatially explicit and depend on soil forming processes closely related to water pathway and residence time (Boulet et al., 1982). In such a context, sampling points were selected based on the morphology of the soil cover and on the water pathways that could be inferred from soil patterns and topography; the continuity and consistency of observed variations along the water pathways will determine the validity of the data.

Three points were located in the podzolic Es horizons, where the DOM-rich water table perched over the Bh-Bhs horizons circulates. The "W1-20" point was situated at $20 \mathrm{~cm}$ depth in the podzolic campinarana area, and the "Spring" point was situated at the very beginning of a spring flowing from the center of the podzolic campinarana area. Both points allowed sampling the upper part of the water table circulating in the sandy podzol horizons. The "W2-150" point was situated $150 \mathrm{~cm}$ in depth within the white sand Es horizon, $50 \mathrm{~cm}$ over the Bh horizon. The "S1-240" point was situated at $240 \mathrm{~cm}$ in depth within the sandy-clay Bhs horizons, where $\mathrm{OM}$ transferred from the soil surface accumulates. The remaining points were chosen along the line of greatest slope in order to obtain a sequence of samples describing changes in the groundwater properties when it passes in depth from the Bh horizons to the kaolin horizons, where bleaching and kaolinite precipitation occur, then flows laterally downslope (points S1-510, S2-490, S3-380, S4-400, S5-380, S6-300) in horizons where gibbsite and iron oxide precipitation occurs. More shallow sampling points were chosen in order to sample groundwater from a perched water table likely circulating in the Ef ferralsol horizon (S2-160, SCB-15, S3-160) and expected to overflow in an U-shaped channel (SCB-15).

\subsubsection{Sampling periods and analysis}

Groundwater was sampled during three periods indicated in Fig. 4. The first one (27 to 30 July 2007) was typical of low rainfall periods, the second one (29 January to 4 February 2008) intermediate, and the third one (19 to 25 May 2008) typical of high rainfall periods, allowing sampling of highlevel water tables. The 10-day cumulated rainfalls before the sampling periods were 53, 88 and $178 \mathrm{~mm}$ for the first, second and third sampling periods, respectively. Complementary sampling for acid-base microtitration and DOC characterization was realized on 9 February 2009 for points Spring, W2-150, S1-240, S1-510, S3-380 and S4-400.

Sampling was done by applying a continuous suction of $25 \mathrm{~mm} \mathrm{Hg}$ to the lysimeters. The first $20 \mathrm{ml}$ of each sampling was discarded in order to avoid dead volume and to rinse the sampling equipment. Groundwater was then sampled until $250 \mathrm{ml}$ was reached or air was entering the system. $\mathrm{pH}$ and $E_{\mathrm{H}}$ were measured immediately after sampling with a Eutech pH310 instrument after stabilization with gentle shake (calibration of the $\mathrm{pH}$ electrode was done every day). Each sample was then filtered using an inline $0.22 \mu \mathrm{m}$ cellulose membrane filter (Nalgene surfactant-free cellulose acetate) and separated in four aliquots for immediate analysis of dissolved $\mathrm{H}_{4} \mathrm{SiO}_{4}, \mathrm{Al}^{3+}, \mathrm{Fe}^{2+}$ and $\mathrm{Fe}^{3+}$, separately. A fifth aliquot was filtered using a $0.7 \mu \mathrm{m}$ fiber glass filter, poisoned with sodium azide, stored in $10 \mathrm{ml}$ vacuum glass flasks (Vacutainer) then kept at low temperature (around $4{ }^{\circ} \mathrm{C}$ ) for laboratory analysis of DOC and other dissolved species.

Analyses of dissolved $\mathrm{H}_{4} \mathrm{SiO}_{4}, \mathrm{Al}^{3+}$ and $\mathrm{Fe}^{2+} / \mathrm{Fe}^{3+}$ were performed within one hour after sampling by colorimetry using a Lange DR 2800 Spectrophotometer with analytical kits LCK301, LCW028 and LCK320, respectively. The measurement ranges were $0.01-0.60 \mathrm{mg} \mathrm{l}^{-1}, 0.005-1.000 \mathrm{mg} \mathrm{l}^{-1}$ and $0.05-6.0 \mathrm{mg} \mathrm{l}^{-1}$ and the absorbencies measured at $620 \mathrm{~nm}$, $695 \mathrm{~nm}$ and $485 \mathrm{~nm}$ for $\mathrm{Al}^{3+}, \mathrm{H}_{4} \mathrm{SiO}_{4}$ and $\mathrm{Fe}^{2+}$, respectively. The colorimetric method was chosen because it allowed measurements immediately after sampling and because it measures the free or displaceable species able to participate to solution-minerals equilibria. To ensure that no oxidation of $\mathrm{Fe}^{2+}$ was occurring between sampling and analysis, $\mathrm{Fe}^{2+}$ measurements were performed 10 minutes and 6 hours after water sampling. No significant differences between the results were observed. As the colored DOM absorbency exponentially decreases from 220 to $650 \mathrm{~nm}$ (Schwartz et al., 2002), DOM contribution is low for $\mathrm{Al}^{3+}$ and $\mathrm{H}_{4} \mathrm{SiO}_{4}$ measurements realized at 620 and $695 \mathrm{~nm}$, respectively, but can be significant for $\mathrm{Fe}^{2+}$ measurement at $485 \mathrm{~nm}$. In order 


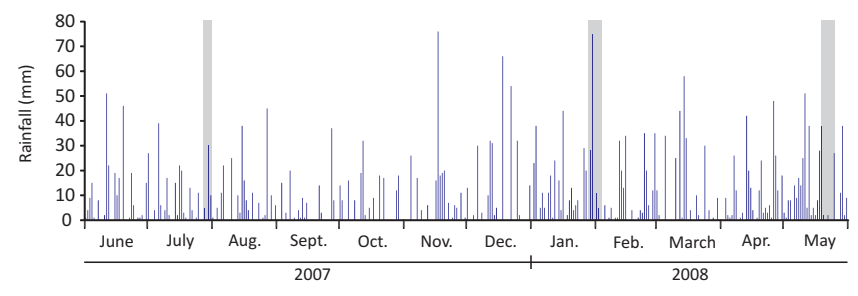

Fig. 4. Daily rainfall in the area. Grey vertical bars indicate the sampling periods.

to limit possible interferences due to the DOM color of the samples, absorbance of the filtered sample before any reagent addition was subtracted from absorbance of the final measurement.

Laboratory analyses were performed between 10 and 45 days after sampling. DOC analyses were performed with a Shimadzu TOC-V Analyzer calibrated with a $10 \mathrm{ppm}$ potassium phthalate standard solution. Blank signal for filtered ultra-pure MQ water was about $0.1 \mathrm{ppm}$. $\mathrm{Na}^{+}, \mathrm{NH}_{4}^{+}$, $\mathrm{K}^{+}, \mathrm{Mg}^{2+}, \mathrm{Ca}^{2+}, \mathrm{F}^{-}, \mathrm{Cl}^{-}, \mathrm{NO}_{2}^{-}, \mathrm{NO}_{3}^{-}, \mathrm{PO}_{4}^{2-}$, and $\mathrm{SO}_{4}^{2-}$ ions were determined by ion chromatography (Dionex DX 120), using $9 \mathrm{mmol}^{-1} \mathrm{NaHCO}_{3}$ for cation elution and $10 \mathrm{mmol}^{-1}$ methane sulfonic acid for anion elution.

Some authors (Menzies et al., 1992) observed that colorimetric methods discriminate against micro-particulates and do not measure all $\mathrm{Al}$ present, as soluble organic forms, and thus underestimate total soluble Al. In order to check if some metal species were so strongly bonded to DOM that they were not displaced during the on-site colorimetric analysis, $\mathrm{Al}^{3+}, \mathrm{Fe}^{2+}$ and $\mathrm{Fe}^{3+}$ were measured for a selected set of samples, before and after UV-oxidation of the DOM (PatelSorrentino et al., 2004). Oxidation was performed in cylindrical quartz vessels using a 450 watt Hanovia Hg lamp; complete DOM oxidation was checked by DOC determination after irradiation. Results gave no significant differences in concentrations before and after UV-oxidation, so that we may conclude that the colorimetric method gave the sum of free plus OM-bonded species for $\mathrm{Al}$ and $\mathrm{Fe}$.

During data modeling, the $\mathrm{pH}$ values seemed underestimated in comparison to field observations, so that special attention was paid to $\mathrm{pH}$ measurements. $\mathrm{pH}$ electrode calibration at field was realized with a standard electrode and standard reference solutions having a ionic strength high when compared to the studied solutions, which can give a measurement error. To test this hypothesis, $\mathrm{pH}$ measurements were achieved on seven selected samples, using the same electrode and adjusting the ionic strength (I) to $10^{-4}, 10^{-3}$ and $10^{-2} \mathrm{M}$ with $\mathrm{KCl}$. The $\mathrm{pH}$ increased with increasing ionic strength, an asymptote being reached when $\mathrm{I}=10^{-2} \mathrm{M}$ (Fig. S1). The difference $\Delta \mathrm{pH}$ between $\mathrm{pH}$ measured before adjustment and $\mathrm{pH}$ measured at $\mathrm{I}=10^{-2} \mathrm{M}$ was dependent on the DOC content, which indicates that the DOM is actually charged and participates to the ionic strength. The
$\mathrm{pH}$ was then corrected by using the empirical relationship $[\Delta \mathrm{pH}=0.508-0.0047 \times \mathrm{DOC}]$ where DOC is expressed in $\mathrm{mg}^{-1}$. In most cases $\Delta \mathrm{pH}$ was between 0.3 and $0.5 \mathrm{pH}$ units; correction was however necessary for modeling. For example, as three $\mathrm{H}^{+}$are exchanged during gibbsite hydrolysis, if $\mathrm{pH}$ increases 0.5 units, the saturation index with regard to gibbsite will increase 1.5 .

In order to evaluate the behavior of the studied solutions with regard to $\mathrm{H}^{+}$, acid-base logarithmic scale microtitrations of selected samples were performed using the procedure describe by Garnier et al. (2004a). Briefly, sample solutions were acidified by $0.2 \mathrm{~mol}^{-1} \mathrm{HNO}_{3}$ additions until $\mathrm{pH} 2.5, \mathrm{~N}_{2}$ purged, and then titrated using $0.1 \mathrm{~mol}^{-1} \mathrm{KOH}$ until $\mathrm{pH}$ 11.5. Acid-base titrations were performed using two Titrino 716 apparatus controlled by a TiNet 2.4 software (Metrohm). The combined pH-micro-electrode used (Mettler, Inlab422, reference: $\mathrm{Ag} / \mathrm{AgCl} / \mathrm{KCl} 3.0 \mathrm{moll}^{-1}$ ) was calibrated daily by the titration of a $\mathrm{HNO}_{3} 0.01 \mathrm{moll}^{-1}$ solution followed by theoretical fitting of the titration curve.

Small carboxylic acids were identified and quantified in selected samples by ionic chromatography (Dionex ICS3000) using AG11-HC guard column, an IonPac ICEAS11 column, for elution $\mathrm{NaOH}$ with a gradient from 1 to $5 \mathrm{mmol}^{-1}$ and a CD25 pulse electrochemical detector. On the same samples, the $\mathrm{SUVA}_{254}$ index was measured using a Shimadzu UV-1800 spectrophotometer. This index is calculated as the ratio of UV absorbance at $254 \mathrm{~nm}$ to the product of DOC and UV cell path length; it is considered as characteristic of the hydrophobicity and aromaticity of the considered DOC (Chin et al., 1994).

Thermodynamic modeling of the solution-minerals interactions was performed by own calculation and checked using the PHREEQC (2.11) software with the WATEQ4F database (Ball and Nordstrom, 1991).

\section{Results}

\subsection{Water pathways along the catena}

During the first sampling period, no samples were available in the S2-160 and S3-160 points because of the lack of perched water table in the Ef horizon due to insufficient rainfall. During the second sampling period, the point S2160 gave a sample only one sampling day (31 January 2008) when the S3-160 point gave a sample three sampling days (29 January 2008, 31 January 2008 and 2 February 2008). During the third sampling period, both S2-160 and S3-160 points gave samples every sampling day. This behavior of the sampling points attests the fast level changes of the perched water table after heavy rains. When sufficiently high, a water table perched over the podzolic Bh-Bhs horizon laterally overflows towards the Ef horizon, then percolates downslope along this horizon or overflows out in the U-shaped channels. Such overflow allows a direct export of the groundwater 
down to the streams and rivers, beside other pathways such as the usual overflowing of the groundwater in the lower parts of the landscape or pipes as observed elsewhere (Lucas et al., 1996). The water sampled at the SCB-15 point during the first sampling period came necessarily from recent rainfall percolating the topsoil horizons, because of the lack of perched water table, when during the second and third sampling the waters could come from both recent rainfalls percolating topsoil horizons and overflowing of the perched water table. Except point S3-380 and downslope point S6-80, other sampling points of the catena gave samples every sampling day.

Two water pathways can therefore be defined along the catena (Fig. 2). A deep, permanent water table flows more than two meters deep within the kaolin horizons. The lateral flow of its upper part corresponds to pathway No. 1 and is described by the following succession of samples: S1-510 S2-490 - S3-380 - S4-400 - S5-380 - S6-300. A temporary, closer to the surface water table circulates in the Es and Ef horizons only after heavy rainfalls and can overflow in the U-shaped channels. It corresponds to pathway No. 2 and is described by the following succession of samples: S1-240 S2-160 - S3-160.

\subsection{Composition of the percolating waters}

The composition of the groundwater from each sampling point and for each sampling day for dissolved $\mathrm{Si}, \mathrm{Al}^{3+}, \mathrm{Fe}^{2+}$, $\mathrm{Fe}^{3+}, \mathrm{pH}, E_{\mathrm{H}}$ and DOC is given in Supplementary Table S1 and summary from these data is given in Table 2. Some key points, representing the different kinds of circulating waters (Spring, W1-20, W2-150, S1-240, S1-510, S2-490, S4-400 and S6-300), were chosen for analyzing other solutes $\left(\mathrm{Na}^{+}\right.$, $\mathrm{NH}_{4}^{+}, \mathrm{K}^{+}, \mathrm{Mg}^{2+}, \mathrm{Ca}^{2+}, \mathrm{Cl}^{-}, \mathrm{NO}_{2}^{-}, \mathrm{NO}_{3}^{-}, \mathrm{SO}_{4}^{2-}, \mathrm{S}^{2-}$ and $\mathrm{F}^{-}$). Results are given in Table 3, except for $\mathrm{S}^{2-}$ and $\mathrm{F}^{-}$ which remained negligible.

The chemistry of the collected waters is hereafter described and discussed following the two water pathways defined above. Overall average compositions of circulating waters are given in Fig. 5 for both pathways. Additional information can be found in Figs. S2 and S3 that give average by sampling periods for pathway No. 1 and No. 2, respectively. For most sampling points, the chemistry of the collected waters showed low variations within a sampling period as well as between sampling periods, as shown by the standard deviations in Figs. 5, S2 and S3.

\subsubsection{From the podzolic sands downslope following the deep water table (pathway No. 1)}

$p H-$ the $\mathrm{pH}$ was acidic for all samples, ranging from 3.4 to 5.5. The minimum values were observed for the waters circulating in the white sand (points W1-20 and W2-150) and in the underlying Bhs (point S1-240) (average 4.1). Regarding the deep water table, the $\mathrm{pH}$ progressively increased downs- lope from point S1-510 (average 4.5) to point S6-300 (average 5.0). The $\mathrm{pH}$ slightly changed from one sampling period to the other, but, considering each sampling period individually, the $\mathrm{pH}$ increase in the downslope direction was always progressive and significant (Fig. S3): t-test values of the difference between points separated by at least 2 other points in the sequence were all but two higher than $2 \mathrm{pH}$ values over 5.2 were only observed for the three points situated at the lower part of the slope (S4-400, S5-380, S6-300).

DOC concentrations - the waters from the upper horizons of the podzolic area (W1-20) had high DOC concentrations; the averages were 46,36 and $27 \mathrm{mgl}^{-1}$ for the first, second and third periods, respectively. The decrease from a period to the other was likely a dilution effect due to higher rainfall. The water sampled at $150 \mathrm{~cm}$ in depth in the white sand (W2-150) had a more buffered composition throughout the three periods $\left(37,37\right.$ and $43 \mathrm{mg} \mathrm{l}^{-1}$, respectively). In the Bhs horizon (S1-240), the DOC concentration varied from 12 to $19 \mathrm{mgl}^{-1}, 15 \mathrm{mgl}^{-1}$ on average. In the deep clayed horizons (points S1-510 to S6-300), the DOC concentrations were lower but non-negligible, varying from 1.5 to $9.7 \mathrm{mg}^{-1}, 4.0 \mathrm{mg}^{-1}$ on average, without significant variations along the catena.

Si and Al concentrations - the waters from the upper horizons of the podzolic area (W1-20) always had very low Si and $\mathrm{Al}$ concentrations; the respective maximum values were 0.1 and $0.14 \mathrm{mg}^{-1}$ and the respective average values were 0.05 and $0.03 \mathrm{mg} \mathrm{l}^{-1}$. On the other hand, the waters from the Bhs horizon (point S1-240) had the highest $\mathrm{Si}$ and $\mathrm{Al}$ values observed during the three sampling periods: Si ranged from 0.29 to $0.59 \mathrm{mg} \mathrm{l}^{-1}$ and $\mathrm{Al}$ ranged from 0.37 to $0.63 \mathrm{mgl}^{-1}$. On every sampling day, the $\mathrm{Si}$ and $\mathrm{Al}$ values were close together (Fig. S2) and the average over the three sampling periods was $0.48 \mathrm{mg} \mathrm{l}^{-1}$ for both. The waters from point W2150 had values intermediate between those of points W120 and S1-240. From the Bhs horizon down to the kaolin horizon, i.e. from point S1-240 to point S1-510, the Si concentrations underwent a decrease by more than half, down to $0.13 \mathrm{mg}^{-1}$ on average, when the $\mathrm{Al}$ values suffered a slighter decrease, down to $0.37 \mathrm{mg}^{-1}$ on average. Going downslope from point $\mathrm{S} 1-510$, the Si values progressively increased again up to values around $0.5 \mathrm{mg} \mathrm{l}^{-1}$. The $\mathrm{Al}$ values continued decreasing progressively.

$F e$ concentrations and $E_{\mathrm{H}}$ - for all points except S3-380, $\mathrm{Fe}^{2+}$ concentrations were higher than $\mathrm{Fe}^{3+}$ concentrations. $\mathrm{Fe}^{3+}$ concentration had, however, similar behavior to that of $\mathrm{Fe}^{2+}$ along the whole catena except the last downslope point. From points W1-20 to S5-380, $\mathrm{Fe}^{3+}$ and $\mathrm{Fe}^{2+}$ concentrations were frequently below the quantification limit and no individual samplings exceeded 0.20 and $0.46 \mathrm{mg}^{-1}$ for $\mathrm{Fe}^{3+}$ and $\mathrm{Fe}^{2+}$, respectively. The points situated upslope in the white sand (W1-20 and W2-150) and in the Bhs horizon (S1-240) had values more variable and higher than the points situated midslope in the deep kaolin (S2-490 to S4-400). Those $\mathrm{Fe}^{3+}$ and $\mathrm{Fe}^{2+}$ values corresponded to $E_{\mathrm{H}}$ 
Table 2. Summary of the composition of the groundwater for each sampling point.

\begin{tabular}{|c|c|c|c|c|c|c|c|c|c|c|c|c|c|}
\hline & \multicolumn{3}{|c|}{$\mathrm{Si}\left(\mathrm{mg} \mathrm{l}^{-1}\right)$} & \multicolumn{3}{|c|}{$\mathrm{Al}^{3+}\left(\mathrm{mg} \mathrm{l}^{-1}\right)$} & \multicolumn{4}{|c|}{$\mathrm{Fe}^{3+}\left(\mathrm{mg} \mathrm{l}^{-1}\right)$} & \multicolumn{3}{|c|}{$\mathrm{Fe}^{2+}\left(\mathrm{mg} \mathrm{l}^{-1}\right)$} \\
\hline & av & $\max$ & $\min$ & av & $\max$ & $\min$ & & av & $\max$ & $\min$ & av & $\max$ & $\min$ \\
\hline Spring & 0.05 & 0.07 & 0.02 & 0.02 & 0.05 & $<0.01$ & & .01 & 0.05 & 0.00 & $<0.05$ & 0.10 & $<0.05$ \\
\hline W1-20 & 0.05 & 0.10 & 0.02 & 0.03 & 0.14 & $<0.01$ & & .03 & 0.07 & 0.00 & 0.06 & 0.13 & $<0.05$ \\
\hline W2-150 & 0.27 & 0.48 & 0.19 & 0.18 & 0.24 & 0.14 & & .04 & 0.15 & 0.00 & 0.10 & 0.38 & $<0.05$ \\
\hline $\mathrm{S} 1-240$ & 0.48 & 0.59 & 0.29 & 0.48 & 0.63 & 0.37 & & .06 & 0.15 & 0.00 & 0.10 & 0.19 & $<0.05$ \\
\hline $\mathrm{S} 1-510$ & 0.13 & 0.20 & 0.10 & 0.37 & 0.41 & 0.33 & & .02 & 0.03 & 0.00 & 0.07 & 0.20 & $<0.05$ \\
\hline SCB-15 & 1.86 & 2.44 & 1.19 & 0.68 & 0.81 & 0.57 & & .79 & 1.65 & 0.39 & 1.58 & 2.52 & 0.42 \\
\hline S2-160 & 0.46 & 0.57 & 0.31 & 0.20 & 0.27 & 0.17 & & .04 & 0.08 & 0.02 & 0.21 & 0.63 & $<0.05$ \\
\hline S2-490 & 0.21 & 0.41 & 0.11 & 0.14 & 0.18 & 0.07 & & .03 & 0.04 & 0.02 & $<0.05$ & 0.09 & $<0.05$ \\
\hline S3-160 & 0.30 & 0.40 & 0.21 & 0.06 & 0.09 & 0.04 & & .01 & 0.04 & 0.00 & 0.05 & 0.15 & $<0.05$ \\
\hline S3-380 & 0.19 & 0.24 & 0.12 & 0.07 & 0.14 & 0.01 & & .02 & 0.05 & 0.00 & $<0.05$ & 0.06 & $<0.05$ \\
\hline S4-400 & 0.49 & 0.71 & 0.25 & 0.03 & 0.07 & $<0.01$ & & .07 & 0.46 & 0.01 & $<0.05$ & 0.07 & $<0.05$ \\
\hline S5-380 & 0.55 & 0.69 & 0.38 & $<0.01$ & 0.01 & $<0.01$ & & .03 & 0.07 & 0.01 & 0.08 & 0.15 & $<0.05$ \\
\hline S6-80 & 0.29 & 0.56 & 0.15 & 0.63 & 0.76 & 0.50 & & .06 & 0.11 & 0.01 & 0.15 & 0.48 & $<0.05$ \\
\hline \multirow[t]{17}{*}{ S6-300 } & 0.48 & 0.57 & 0.24 & 0.09 & 0.11 & 0.08 & & .06 & 0.13 & 0.03 & 0.74 & 1.11 & 0.52 \\
\hline & & & \multicolumn{3}{|c|}{$\mathrm{pH}$} & \multicolumn{3}{|c|}{$E_{\mathrm{H}}(\mathrm{mV})$} & \multicolumn{3}{|c|}{$\mathrm{DOC}\left(\mathrm{mg} \mathrm{l}^{-1}\right)$} & & \\
\hline & & & av & $\max$ & $\min$ & av & $\max$ & $\min$ & av & $\max$ & $\min$ & & \\
\hline & & Spring & 4.0 & 4.3 & 3.4 & 521 & 542 & 503 & 37 & 45 & 29 & & \\
\hline & & W1-20 & 4.1 & 4.5 & 3.6 & 473 & 495 & 451 & 34 & 55 & 24 & & \\
\hline & & W2-150 & 4.2 & 4.5 & 3.9 & 512 & 563 & 472 & 40 & 52 & 35 & & \\
\hline & & S1-240 & 4.1 & 4.4 & 3.5 & 501 & 567 & 410 & 15 & 19 & 12 & & \\
\hline & & $\mathrm{S} 1-510$ & 4.5 & 5.1 & 3.8 & 514 & 575 & 468 & 2 & 3 & 2 & & \\
\hline & & SCB-15 & 4.6 & 5.1 & 4.0 & 372 & 415 & 325 & 32 & 38 & 27 & & \\
\hline & & $S 2-160$ & 4.6 & 5.1 & 3.8 & 399 & 484 & 296 & 7 & 9 & 6 & & \\
\hline & & S2-490 & 4.6 & 5.1 & 3.9 & 499 & 543 & 444 & 4 & 7 & 2 & & \\
\hline & & S3-160 & 4.9 & 5.2 & 4.7 & 482 & 519 & 448 & 5 & 10 & 4 & & \\
\hline & & S3-380 & 4.9 & 5.2 & 4.6 & 494 & 532 & 467 & 4 & 6 & 2 & & \\
\hline & & S4-400 & 4.8 & 5.3 & 4.1 & 494 & 520 & 482 & 5 & 9 & 2 & & \\
\hline & & S5-380 & 4.9 & 5.4 & 4.3 & 460 & 478 & 437 & 3 & 5 & 2 & & \\
\hline & & S6-80 & 4.5 & 5.1 & 4.1 & 456 & 510 & 365 & 16 & 19 & 13 & & \\
\hline & & S6-300 & 5.0 & 5.5 & 4.4 & 172 & 191 & 147 & 5.4 & 9.7 & 3.5 & & \\
\hline
\end{tabular}

values varying from 410 to $575 \mathrm{mV}$, without significant correlation between these variables. Downslope, the behaviors of $\mathrm{Fe}^{3+}$ and $\mathrm{Fe}^{2+}$ concentrations diverged: when the $\mathrm{Fe}^{3+}$ concentrations remained low, the $\mathrm{Fe}^{2+}$ concentrations increased slightly on point S5-380 then drastically on point S6-300 with a $0.57 \mathrm{mg}^{-1}$ average value, this increase being related to a decrease of the $E_{\mathrm{H}}$ below $253 \mathrm{mV}$.

The waters from the Spring point had $\mathrm{pH}$ and chemical characteristics very similar to those observed for the W1-20 point, except regarding the $E_{\mathrm{H}}$ which was higher $(521 \pm 15$ versus $473 \pm 17 \mathrm{mV}$ ).

\subsubsection{From the podzolic sands downslope following the perched water table (pathway No. 2)}

pH and DOC concentrations - the transition from the point S1-240 to the points S2-160 then S3-160 came with a pH increase between 0.5 and $1 \mathrm{pH}$ unit $(4.1,4.6$ and 4.9 on average, respectively) and a progressive decrease of the DOC concentrations $\left(15,5\right.$ and $4 \mathrm{mg}^{-1}$ on average, respectively).
The point SCB-15 had $\mathrm{pH}$ values similar to those of points S2-160 and S3-160 (4.6 on average), but DOC values always higher than $27 \mathrm{mg} \mathrm{l}^{-1}$ (32 $\mathrm{mg} \mathrm{l}^{-1}$ on average).

Si and Al concentrations - the Si concentrations slightly decreased when passing from point S1-240 (average $0.48 \mathrm{mg} \mathrm{l}^{-1}$ ) to point $\mathrm{S} 2-160$ (average $0.46 \mathrm{mg} \mathrm{l}^{-1}$ ), then decreased markedly on point S3-160 (average $0.30 \mathrm{mg} \mathrm{l}^{-1}$ ). Al concentrations already decreased markedly when passing from point $\mathrm{S} 1-240$ (average $0.48 \mathrm{mg} \mathrm{l}^{-1}$ ) to point $\mathrm{S} 2-160$ (average $0.30 \mathrm{mg} \mathrm{l}^{-1}$ ), then continued decreasing on point S3160 (average $0.06 \mathrm{mg} \mathrm{l}^{-1}$ ). This resulted in a progressive increase of the $\mathrm{Si} / \mathrm{Al}$ molar ratio based on average values: 1.0 at point S1-240, 2.3 at point $\mathrm{S} 2-160$ and 4.8 at point S3-160. The waters sampled from point SCB-15 were characterized by high $\mathrm{Si}$ and $\mathrm{Al}$ concentrations when compared to the other sampling points, on average 1.86 and $0.68 \mathrm{mg} \mathrm{l}^{-1}$ for $\mathrm{Si}$ and $\mathrm{Al}$, respectively, with a $\mathrm{Si} / \mathrm{Al}$ molar ratio varying between 1.8 and 4.1 (2.7 for the average of ratios). 
Table 3. Major ions charge, DOC and $\mathrm{pH}$ (average \pm standard deviation).

\begin{tabular}{|c|c|c|c|c|c|c|c|c|}
\hline \multirow{2}{*}{$\begin{array}{l}\text { Sampling } \\
\text { point }\end{array}$} & \multirow{2}{*}{$\begin{array}{l}\text { Number of } \\
\text { samples }\end{array}$} & \multicolumn{7}{|c|}{ Major ions charge } \\
\hline & & $\begin{array}{l}\mathrm{Na}^{+} \\
\left(\mu \mathrm{eq} 1^{-1}\right)\end{array}$ & $\begin{array}{l}\mathrm{NH}_{4}^{+} \\
\left(\mu \mathrm{eq} 1^{-1}\right)\end{array}$ & $\begin{array}{l}\mathrm{K}^{+} \\
\left(\mu \mathrm{eq} 1^{-1}\right)\end{array}$ & $\begin{array}{l}\mathrm{Mg}^{2+} \\
\left(\mu \mathrm{eq} \mathrm{l}^{-1}\right)\end{array}$ & $\begin{array}{l}\mathrm{Ca}^{2+} \\
\left(\mu \mathrm{eq} 1^{-1}\right)\end{array}$ & $\begin{array}{l}\mathrm{Al}^{\mathrm{a}} \\
\left(\mu \mathrm{eq} 1^{-1}\right)\end{array}$ & $\begin{array}{l}\mathrm{Fe}^{2+} \\
\left(\mu \mathrm{eq} 1^{-1}\right)\end{array}$ \\
\hline Spring & 4 & $24.7 \pm 2.5$ & $9.7 \pm 4.5$ & $8.9 \pm 2.0$ & $10.3 \pm 3.0$ & $103.0 \pm 26.4$ & $2.2 \pm 2.6$ & $1.0 \pm 0.5$ \\
\hline W1-20 & 1 & 26.4 & 3.8 & 36.5 & 12.6 & 82.8 & 3.3 & 2.2 \\
\hline W2-150 & 1 & 34.2 & 64.5 & 35.1 & 15.8 & 88.6 & 19.5 & 3.6 \\
\hline $\mathrm{S} 1-240$ & 4 & $30.2 \pm 13.7$ & $13.4 \pm 19.1$ & $19.7 \pm 15.5$ & $7.8 \pm 2.7$ & $46.4 \pm 15.6$ & $52.8 \pm 4.5$ & $3.6 \pm 3.8$ \\
\hline$S 1-510$ & 4 & $14.8 \pm 2.1$ & $4.8 \pm 6.1$ & $5.0 \pm 1.3$ & $4.7 \pm 1.4$ & $34.7 \pm 8.5$ & $39.6 \pm 3.4$ & $2.2 \pm 1.1$ \\
\hline S2-490 & 4 & $27.6 \pm 13.2$ & $33.6 \pm 28.2$ & $8.7 \pm 6.9$ & $3.9 \pm 1.4$ & $53.2 \pm 12.7$ & $15.0 \pm 5.5$ & $1.4 \pm 0.8$ \\
\hline S4-400 & 4 & $36.9 \pm 10.4$ & $31.4 \pm 19.4$ & $43.2 \pm 6.6$ & $9.9 \pm 1.4$ & $73.9 \pm 12.4$ & $3.3 \pm 2.3$ & $1.4 \pm 0.9$ \\
\hline \multirow[t]{2}{*}{ S6-300 } & 4 & $18.1 \pm 2.7$ & $16.4 \pm 10.0$ & $30.4 \pm 1.7$ & $4.9 \pm 0.5$ & $61.6 \pm 8.4$ & $9.0 \pm 5.2$ & $26.4 \pm 14.3$ \\
\hline & & $\begin{array}{l}\mathrm{Fe}^{\mathrm{III} \text { a }} \\
\left(\mu \mathrm{eq} 1^{-1}\right)\end{array}$ & $\begin{array}{l}\mathrm{Cl}^{-} \\
\left(\mu \mathrm{eq} 1^{-1}\right)\end{array}$ & $\begin{array}{l}\mathrm{NO}_{2}^{-} \\
\left(\mu \mathrm{eq} 1^{-1}\right)\end{array}$ & $\begin{array}{l}\mathrm{NO}_{3}^{-} \\
\left(\mu \mathrm{eq} 1^{-1}\right)\end{array}$ & $\begin{array}{l}\mathrm{SO}_{4}^{2-} \\
\left(\mu \mathrm{eq} 1^{-1}\right)\end{array}$ & $\mathrm{pH}^{\mathrm{b}}$ & $\begin{array}{l}\text { DOC } \\
\left(\mathrm{mg} \mathrm{l}^{-1}\right)\end{array}$ \\
\hline Spring & 4 & $0.6 \pm 0.2$ & $11.5 \pm 4.1$ & $0.0 \pm 0.0$ & $3.6 \pm 6.2$ & $11.1 \pm 1.2$ & $4.0 \pm 0.08$ & $37.4 \pm 1.9$ \\
\hline W1-20 & 1 & 1.5 & 8.2 & 4.1 & 8.6 & 8.6 & 4.1 & 34.4 \\
\hline W2-150 & 1 & 2.1 & 19.7 & 32.3 & 8.9 & 35.1 & 4.2 & 40.2 \\
\hline $\mathrm{S} 1-240$ & 4 & $3.9 \pm 2.6$ & $16.6 \pm 9.9$ & $0.0 \pm 0.0$ & $74.6 \pm 10.8$ & $24.2 \pm 9.4$ & $4.0 \pm 0.09$ & $15.2 \pm 0.7$ \\
\hline S1-510 & 4 & $1.2 \pm 0.5$ & $11.2 \pm 2.8$ & $2.0 \pm 2.0$ & $41.8 \pm 7.2$ & $17.4 \pm 6.2$ & $4.6 \pm 0.08$ & $2.3 \pm 0.4$ \\
\hline S2-490 & 4 & $1.5 \pm 0.6$ & $13.3 \pm 9.7$ & $0.0 \pm 0.0$ & $11.2 \pm 5.1$ & $22.8 \pm 7.1$ & $4.6 \pm 0.13$ & $4.0 \pm 1.6$ \\
\hline S4-400 & 4 & $3.9 \pm 1.8$ & $32.5 \pm 18.1$ & $3.9 \pm 3.9$ & $23.4 \pm 10.4$ & $34.7 \pm 14.1$ & $4.8 \pm 0.07$ & $4.9 \pm 2.0$ \\
\hline S6-300 & 4 & $3.3 \pm 0.9$ & $12.5 \pm 1.1$ & $0.0 \pm 0.0$ & $6.5 \pm 4.6$ & $15.0 \pm 4.3$ & $5.1 \pm 0.17$ & $5.4 \pm 0.9$ \\
\hline
\end{tabular}

a Calculated for the sum of $\mathrm{Al}$ or $\mathrm{Fe}^{\mathrm{III}}$ species, respectively.

b Values after correction; see text.
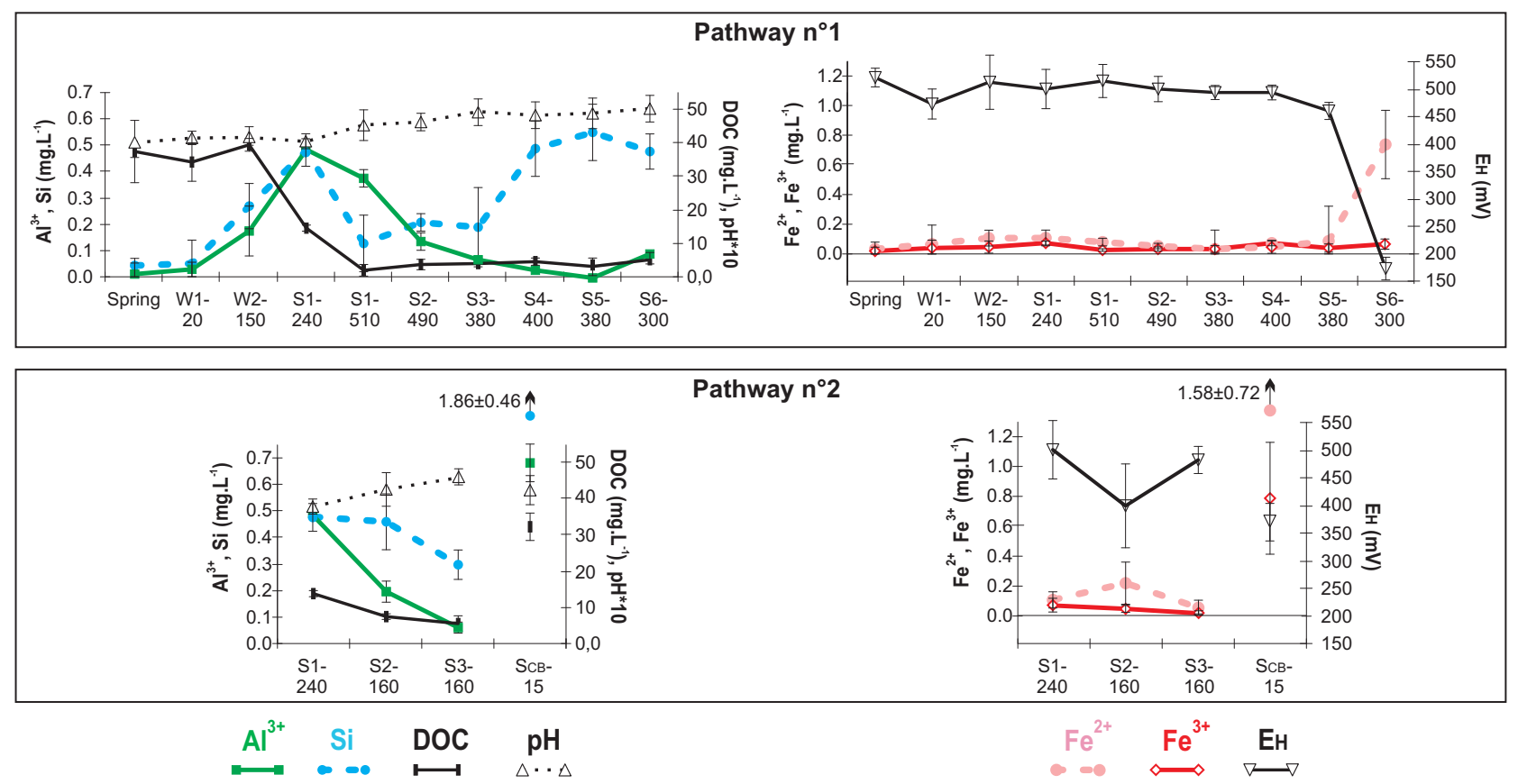

Fig. 5. Average composition of the sampled waters along the pathways No. 1 and No. 2. Vertical bars give the calculated standard deviation for each set of data. 
$\mathrm{Fe}^{2+}, \mathrm{Fe}^{3+}$ concentrations and $\mathrm{E}_{\mathrm{H}}-$ the $\mathrm{Fe}^{2+}$ concentrations increased when passing from point $\mathrm{S} 1-240\left(0.10 \mathrm{mg}^{-1}\right.$ on average) to point $\mathrm{S} 2-160\left(0.21 \mathrm{mg}^{-1}\right.$ on average), then decreased on point $\mathrm{S} 3-160\left(0.05 \mathrm{mgl}^{-1}\right.$ on average). The $\mathrm{Fe}^{2+}$ concentrations on point S2-160 exhibited, however, a high variability, with a standard deviation (0.24) higher than the average value. The high $\mathrm{Fe}^{2+}$ concentrations were always related to lower $E_{\mathrm{H}}$ values, which reflect on the average values of $E_{\mathrm{H}}: 501,399$ and $482 \mathrm{mV}$ for points S1-240, S2-160 and S3-160, respectively. There is no, however, correlation between the bulk of $\mathrm{Fe}^{2+}$ and $E_{\mathrm{H}}$ values $\left(R^{2}=0.23\right)$. The $\mathrm{Fe}^{3+}$ concentrations remained always lower than $0.08 \mathrm{mg} \mathrm{l}^{-1}$ for both S2-160 and S3-160 points. The waters sampled at point $\mathrm{SCB}-15$ had high $\mathrm{Fe}^{2+}$ and $\mathrm{Fe}^{3+}$ concentrations (on average 1.58 and $0.79 \mathrm{mg} \mathrm{l}^{-1}$, respectively) when compared to any other sampling point, and relatively low $E_{\mathrm{H}}$ values ( $372 \mathrm{mV}$ on average).

\subsection{DOM characterization}

Microtitrations were performed on samples collected at Spring and W2-150 points. An example of microtitration curve is given in Fig. 6. Three repetitions were made for each sample. The acid-base properties of the DOC were evaluated by fitting these results with the PROSECE software (Garnier et al., 2004a, b) which consider a discrete distribution of acidic sites whose acidic constants $\mathrm{pKa}_{i}$ and site densities $\mathrm{L}_{\mathrm{T}, i}$ are determined by fitting the experimental curves. The optimal number of acidic sites is defined as the simplest combination that conduces to the minimal fitting bias value (sum of the absolute differences between experimental and calculated $\mathrm{pH}$ values). Accordingly, a distribution of 4 acidic sites was sufficient to allow a correct fitting of experimental curves. The results are given in Table 4 . The total calculated site densities were $40.2 \pm 6.1$ and $27.2 \pm 3.6 \mathrm{meq} \mathrm{gC}^{-1}$ for the Spring and the W2-150 samples, respectively.

Small carboxylic acid identification and quantification for samples collected at points Spring, W2-150, S1-510, S3-380 and S4-400 are given in Table 5. With regard to the total of the identified small carboxylic acids, acetic acid represented between 38 and $61 \%$, formic, succinic, oxalic and citric acids between 4 and $27 \%$, and lactic acid remained lower than $4 \%$. The sum of small carboxylic acids was higher than $2 \mathrm{mgCl}^{-1}$ in the DOC-rich samples and lower than $1 \mathrm{mglCl}^{-1}$ in the DOC-poor samples. The proportion of small carboxylic acids in the DOC, however, was lower than $10 \%$ in the DOC-rich samples (Spring and W2-150) and higher than $47 \%$ for the other samples. The $\mathrm{SUVA}_{254}$ index (Table 5) values are in accordance with these results. The two DOC-rich samples exhibited a SUVA 254 index more than two times higher than those of the DOC-poor samples, which indicate that the former contain many more humic substances than the latter.
Table 4. Result of modeling the microtitration curves by 4 discrete acidic sites $-\mathrm{pKa}$ and site density $L_{\mathrm{T}}$.

\begin{tabular}{lllll}
\hline Spring & & & & \\
\hline $\mathrm{pKa}$ & $3.5 \pm 0.6$ & $4.7 \pm 0.4$ & $6.9 \pm 2.6$ & $9.3 \pm 1.5$ \\
$L_{\mathrm{T}}($ meq gC & -1 \\
$\mathrm{~W} 2-150$ & $17.2 \pm 0.4$ & $9.5 \pm 0.4$ & $8.1 \pm 2.3$ & $5.4 \pm 5.6$ \\
$\mathrm{pKa}$ & & & & \\
$L_{\mathrm{T}}($ meq gC & \\
& $4.1 \pm 0.3$ & $5.2 \pm 0.1$ & $8.7 \pm 0.1$ & $10.6 \pm 0.1$ \\
& $10.9 \pm 0.3$ & $7.1 \pm 0.5$ & $2.6 \pm 0.3$ & $6.6 \pm 3.5$ \\
\hline
\end{tabular}

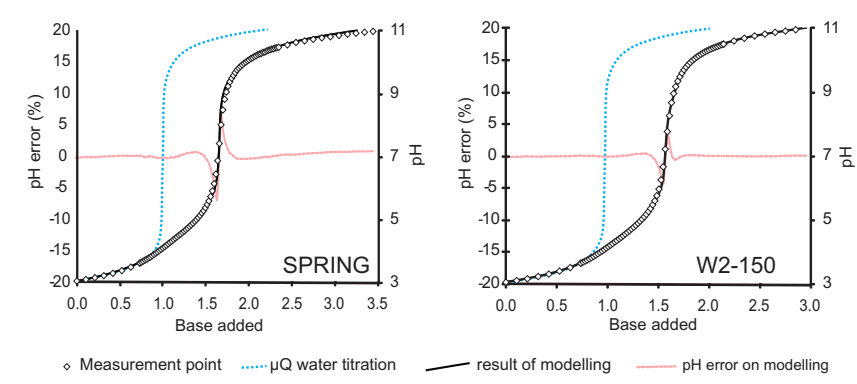

Fig. 6. Microtitration curves of DOM-rich groundwaters and result of modeling with the PROSECE software.

\section{Discussions and conclusion}

\subsection{Evolution of the percolating waters along the catena}

\subsubsection{Waters in the podzolic area}

The spring water and the water circulating in the upper part of the white sands had the highest DOC and the lower $\mathrm{pH}$ and $\mathrm{Si}$ values compared to all other samples and very low $\mathrm{Al}, \mathrm{Fe}^{2+}$ and $\mathrm{Fe}^{3+}$ values, in the range of values observed by Cornu et al. $(1997,1998)$ in a similar podzolic area - similar soil and vegetation - situated near Manaus. Dissolved Si, $\mathrm{Al}$ and $\mathrm{Fe}$ found here can come from canopy leaching, litter mineralization and dissolution of quartz and trace minerals. This water is aggressive with regard to clay or iron minerals, due to its acidity and complexing capacity of the DOC which greatly enhances the weathering rates (Robert and Berthelin, 1986). When it reaches the transition between white sands and kaolin horizon, in the Bh-Bhs horizons, it dissolves kaolinite and $\mathrm{Fe}$ - or $\mathrm{Al}$-oxides so that the concentrations of $\mathrm{Si}, \mathrm{Al}$ and $\mathrm{Fe}$ in the percolating water increase. The dissolved $\mathrm{Si} / \mathrm{Al}$ molar ratio in the Bhs horizons was very close to 1 , which is in accordance with a congruent dissolution of kaolinite. The up and down movements of the water table perched over the Bh-Bhs favor the upward dispersion of solutes, which explains that concentrations at medium depth in the white sands are intermediate between concentrations at the topsoil and within the Bhs. The decrease of DOC concentration when water passes through the Bh-Bhs is due to the DOC adsorption on kaolinite or Fe-oxides and gibbsite surfaces (Davis, 1982; Kaiser and Zech, 2000). Such adsorption was observed in Amazonian podzols everywhere 
Table 5. DOC characterization.

\begin{tabular}{lrrrrr}
\hline & Spring & W2-150 & S1-510 & S3-380 & S4-400 \\
\hline \multicolumn{5}{c}{ DOC and small carboxylic acids $\left(\mathrm{mgC}^{-1}\right)$} \\
\hline DOC & 35.6 & 38.3 & 1.3 & 1.7 & 2.1 \\
Lactic acid & 0.05 & 0.05 & 0.02 & 0.04 & 0.02 \\
Acetic acid & 0.28 & 0.17 & 0.10 & 0.17 & 0.24 \\
Formic acid & 1.18 & 1.10 & 0.44 & 0.62 & 0.60 \\
Succinic acid & 0.64 & 0.56 & 0.11 & n.a. & n.a. \\
Oxalic acid & 0.26 & 0.19 & 0.09 & 0.04 & n.a. \\
Citric acid & 0.72 & n.a. & 0.07 & 0.12 & 0.13 \\
\hline & \multicolumn{5}{c}{ SUVA $_{254}$ index $\left(1 \mathrm{mg}^{-1} \mathrm{~m}^{-1}\right)$} \\
\hline
\end{tabular}

a DOC-rich water table circulating in a quite sandy material passes through a material having some clay or oxides (Chauvel et al., 1987; Bardy et al., 2008; Fritsch et al., 2009).

\subsubsection{Waters in the kaolin horizons (pathway No. 1)}

Passing from the Bhs to the underlying deep kaolin, the water exhibited a slight $\mathrm{pH}$ increase, a drastic decrease of DOC, a decrease of $\mathrm{Si}$ and a slight decrease of $\mathrm{Al}$ and $\mathrm{Fe}$. $\mathrm{Si}, \mathrm{Al}$ and $\mathrm{Fe}$ variations in percolating waters as well as the higher content of gibbsite and Fe-oxides at the upper part of the kaolin horizons can be explained by the following considerations. The DOM that migrates through the sandy horizons is carrying complexed $\mathrm{Al}$ and $\mathrm{Fe}$ (Benedetti et al., 2003; Fritsch et al., 2009). Most organometallic complexes adsorb on mineral surfaces in the Bh-Bhs but do not accumulate indefinitely, and most of them will eventually be mineralized, releasing $\mathrm{Al}$ and $\mathrm{Fe}$ in the soil solution. The assumption of a relatively rapid turn-over of the $\mathrm{OM}$ is strengthened by the young apparent ${ }^{14} \mathrm{C}$ ages $(<3000 \mathrm{yr})$ measured for a NOM from a similar deep Bh in the Manaus area (Montes et al., 2011). Fe precipitates as Fe-oxides (likely goethite and lepidocrocite) and Al precipitates as kaolinite, resulting in the decrease of the $\mathrm{Si}$ concentration. Al, when in excess, precipitates as gibbsite, giving high gibbsite content in the horizons immediately beneath the Bhs.

Going downslope in the deep kaolin horizons, the $\mathrm{pH}$ increase is more related to an increase of the sum of charges of major ions than to a decrease of the DOM charge (Table 6). The increase of $\mathrm{Na}^{+}, \mathrm{K}^{+}, \mathrm{Ca}^{2+}$ and $\mathrm{Mg}^{2+}$ concentrations when going downslope is likely due to higher content in weatherable minerals closer to the soil surface. The $\mathrm{pH}$ increase could explain the precipitation of $\mathrm{Al}$ as gibbsite nodules (Fig. 2) and the consecutive decrease of $\mathrm{Al}$ concentration in the soil solution (Fig. 5).

\subsubsection{Waters in the perched water table (pathway No. 2)}

When flowing from the white sand to the non-podzolic leached horizon Ef, passing the Bh-Bhs, the groundwater lost most of its DOC, but remained with DOC concentrations higher than $5 \mathrm{mgl}^{-1}$, thus aggressive with regard to secondary minerals. It can therefore favor the clay impoverishment of the Ef horizon with a positive feedback due to higher water flow after clay impoverishment. The increase of the $\mathrm{Si} / \mathrm{Al}$ molar ratio can be explained by precipitation of $\mathrm{Al}$ as gibbsite as observed downslope along the pathway No. 1. In the channel bottom water $\mathrm{Si}, \mathrm{Al}$ and $\mathrm{Fe}$ values are exceptionally high with regard to the high rainfall climate; $\mathrm{Si}$ values for example may approach the quartz solubility $\left(2.9 \mathrm{mg} \mathrm{l}^{-1}\right)$. This may be due to the fact that the water sampled at this point added dissolved elements brought by the overflowing groundwater and elements locally produced by the litter degradation. It has indeed been shown that the forest recycles a great amount of Si through litterfall and that litter dissolution in the topsoil can increase groundwater $\mathrm{Si}$ concentration up to saturation with kaolinite (Lucas, 2001).

\subsection{The properties of the dissolved organic matter}

The remaining negative charges due to the DOM $\left(Z_{\mathrm{DOM}}\right)$ were calculated in order to calculate the DOM acid site density. Table 6 reports the ion balance for the samples given in Table 3. $Z_{\mathrm{DOM}}$ expressed in meq $\mathrm{C}^{-1}$ was calculated from the sum of charges of major ions $\sum_{i} z_{i}$ expressed in $\mu$ eq $1^{-1}$, the $\mathrm{pH}$ and the dissolved organic carbon concentration expressed in $\mathrm{mg}^{-1}$, using the following equation:

$Z_{\mathrm{DOM}}=\frac{\left(10^{-6 \mathrm{pH}}-\sum_{i} z_{i}\right)}{\mathrm{DOC}}$.

The average DOM charge ranged from -6.2 to -6.5 meq gC $^{-1}$ for the water circulating in the white sand, was $-11 \mathrm{meq} \mathrm{gC}^{-1}$ for the water in the Bhs, and ranged from -31 to -37 meq $\mathrm{gC}^{-1}$ for the waters circulating in the deep kaolinitic horizons. The DOM circulating in the kaolinitic horizons had therefore values much higher than the DOM from the white sands. As all the waters were quite acidic, most of these charges were due to carboxylictype sites. The acid site density $L_{\mathrm{T}}$ expressed in meq $\mathrm{gC}^{-1}$ was approximated by modeling for a single carboxylic-type ligand, considering various pKa from 3 to 4.5, using the following equation:

$L_{\mathrm{T}}=Z_{\mathrm{DOM}}\left(1+10^{\mathrm{pKa}-\mathrm{pH}}\right)$.

The results are given in Table 6. The calculated acid-site densities of the DOM circulating in the white sands range from 7 to 23 meq gC ${ }^{-1}$ when considering a pKa ranging from 3 to 4.5 . This is consistent with the values obtained by modeling the microtitration curves for the Spring and W2-150 points $\left(26.7 \pm 0.8\right.$ and $18.0 \pm 0.8 \mathrm{meq} \mathrm{gC}^{-1}$ for carboxylictype sites, respectively) (Table 4). Regarding carboxylic-type 
Table 6. Calculated charge due to DOM and acid site density for various pKa.

\begin{tabular}{|c|c|c|c|c|c|c|c|c|c|}
\hline \multirow{3}{*}{$\begin{array}{l}\text { Sampling } \\
\text { point }\end{array}$} & \multirow{3}{*}{$\begin{array}{l}\text { Number of } \\
\text { samples }\end{array}$} & \multirow{3}{*}{$\begin{array}{l}\text { Sum of charges } \\
\text { of major ions } \\
\left(\mu \mathrm{eq} \mathrm{l}^{-1}\right)\end{array}$} & \multirow[t]{3}{*}{$\mathrm{pH}$} & \multirow{3}{*}{$\begin{array}{l}\text { DOC } \\
\left(\mathrm{mg}^{-1}\right)\end{array}$} & \multirow{3}{*}{$\begin{array}{l}\text { Charge due } \\
\text { to } \mathrm{DOM}_{\mathrm{DOM}} \\
\left(\text { meq } \mathrm{gC}^{-1}\right)\end{array}$} & \multicolumn{4}{|c|}{ Acid-site density $L_{\mathrm{T}}\left(\right.$ meq gC $\left.\mathrm{C}^{-1}\right)$} \\
\hline & & & & & & \multicolumn{4}{|c|}{ pKa } \\
\hline & & & & & & 3.0 & 3.5 & 4.0 & 4.5 \\
\hline Spring & 4 & $134 \pm 28$ & $4.0 \pm 0.08$ & $37.4 \pm 2.9$ & $-6.3 \pm 1.8$ & $7 \pm 2$ & $8 \pm 3$ & $13 \pm 5$ & $26 \pm 11$ \\
\hline W1-20 & 1 & 142 & 4.1 & 34.4 & -6.5 & 7 & 8 & 12 & 23 \\
\hline W2-150 & 1 & 184 & 4.2 & 40.2 & -6.2 & 7 & 7 & 10 & 19 \\
\hline S1-240 & 4 & $59 \pm 36$ & $4.0 \pm 0.09$ & $15.2 \pm 0.7$ & $-11 \pm 4$ & $12 \pm 4$ & $14 \pm 6$ & $22 \pm 10$ & $46 \pm 22$ \\
\hline S1-510 & 4 & $33 \pm 3$ & $4.6 \pm 0.08$ & $2.3 \pm 0.4$ & $-31 \pm 4$ & $31 \pm 4$ & $33 \pm 5$ & $38 \pm 7$ & $55 \pm 12$ \\
\hline S2-490 & 4 & $98 \pm 39$ & $4.6 \pm 0.13$ & $4.0 \pm 0.7$ & $-37 \pm 13$ & $38 \pm 14$ & $40 \pm 15$ & $47 \pm 18$ & $67 \pm 29$ \\
\hline S4-400 & 4 & $109 \pm 29$ & $4.8 \pm 0.07$ & $4.9 \pm 2.0$ & $-32 \pm 8$ & $33 \pm 8$ & $34 \pm 9$ & $37 \pm 10$ & $48 \pm 15$ \\
\hline S6-300 & 4 & $135 \pm 27$ & $5.1 \pm 0.17$ & $5.4 \pm 0.9$ & $-32 \pm 5$ & $32 \pm 5$ & $33 \pm 5$ & $34 \pm 6$ & $40 \pm 8$ \\
\hline
\end{tabular}

acid site densities, we found no data for equatorial podzols or ferralsol groundwater available in the literature. In comparison, Ravichandran et al. (1998) obtained a total of acid-site

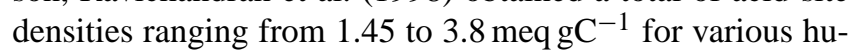
mic substances ( $\mathrm{AF}$ and $\mathrm{AH}$ ) coming from the Everglades and from Suwanee River, i.e. lower values than reported here. Considering natural waters, total carboxylic acid site densities obtained in pristine boreal areas (Köhler et al., 1999; Cuss et al., 2010) or springs from acid podzolic temperate zone (Hruska et al., 2003) were $8.6 \pm 1.6,9.8 \pm 0.24$ and $10.2 \pm 0.6$ meq $\mathrm{gC}^{-1}$, respectively. These values are in the range of those reported here.

The DOM circulating in depth in the kaolinitic horizons was quite different. Considering a $\mathrm{pKa}$ ranging from to 3 or 4.5 , the calculated site densities are quite high, ranging

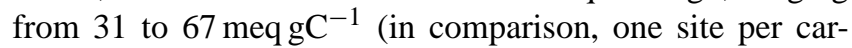

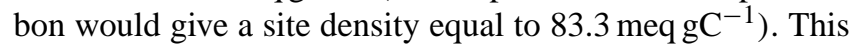
is consistent with the higher proportion of small carboxylic acids observed in the DOC-poor groundwaters: site densities of formic, oxalic, acetic, citric, succinic and lactic acids are

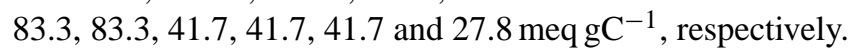
This is also consistent with the low SUVA $_{254}$ values of the DOC-poor groundwaters indicating a low proportion of humic substances.

The dynamics of the DOC in the soil system can thus be described as follows. The DOM circulating in the white sand has a high proportion of humic compounds and less than $10 \%$ of small carboxylic acids. When the groundwater passes through the Bh-Bhs, most of the DOM is adsorbed, resulting in a more than 10 -fold decrease of the DOC content. The dissolved humic substances are preferentially adsorbed, so that the proportion of small carboxylic acids increases up to around $50 \%$ of the total DOC. It is however impossible to determine if these small carboxylic acids are a fraction of the DOM that came from the white sands or if they were produced by microbial activity in the Bh-Bhs. The ability of small carboxylic compounds to percolate through a kaolinitic material can be explained by the fact that they are more hydrophilic than larger, humified components usually hydrophobic. It is in accordance with results obtained by Kang and Xing (2007), which showed that the adsorption of carboxylic acids on clay surfaces is lower when the compounds are small and is lower on kaolinite than on $2: 1$ clays. Kaiser and Zech (2000) showed that the sorption of DOM on the clay fraction is sharply reduced when Fe-oxides and gibbsite are removed from the clay fraction. Indeed, the Fe-oxides and gibbsite contents are very low in the white kaolin horizon. When the solutions percolating in the white kaolin reach a material with a higher content in Fe-oxides and gibbsite, the DOM can be adsorbed, and then mineralized, resulting in the release of previously DOM-complexed $\mathrm{Al}$ or Fe and a positive feedback for Fe-oxides and gibbsite precipitation.

\subsection{Groundwater - minerals relationships}

\subsubsection{The Si-Al system}

The positions of the average groundwaters in the Si-Al system are given in Fig. 7. The line "kaolinite 1" corresponds to the stability with kaolinite calculated with the WATEQ4F database, which uses the same value $\left(\log \left(K_{\mathrm{sp}}\right)=3.705\right)$ as the one proposed by Tardy and Nahon (1985) after a critical analysis of the literature. However, as stressed by Grimaldi et al. (2004), kaolinite solubility is not well defined in most tropical soils because of iron substitution and variable crystallinity, and these authors also used a lower value (Log $\left(K_{\mathrm{sp}}\right)=2.853$ ) that gave the line "kaolinite 2" in Fig. 7 .

Even without considering complexation by DOM, the spring water and the groundwater circulating in the upper part of the white sands (Spring and W1-20) are far away from saturation with kaolinite or gibbsite. Except point S5380 , the groundwaters circulating in the kaolinitic horizons (from S1-510 to S6-300 along the pathway No. 1 and from S3-160 to S2-160 along the pathway No. 2) are distributed between the two kaolinite lines, which indicate a control by kaolinite precipitation/dissolution. The increase of Si concentrations downslope (white arrow), i.e. with increasing residence time, is likely due to quartz dissolution. These waters are supersaturated with regard to gibbsite, which is consistent with gibbsite precipitation in slope horizons (see envelope of centimetrical Al-nodules in Fig. 2) but may also indicate a higher gibbsite solubility or Al complexation with DOM. No 


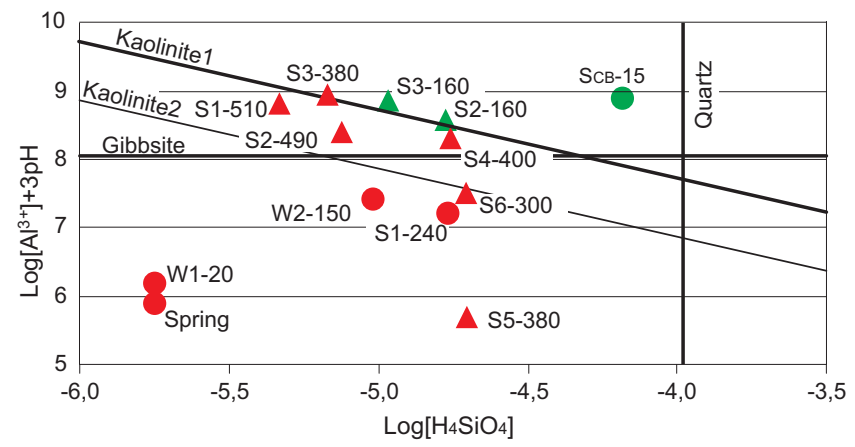

Fig. 7. Position of the groundwaters in the Si-Al system calculated from the average compositions without considering complexation by DOM. Red and green symbols indicate groundwaters following pathway No. 1 and No. 2, respectively. Triangular symbols indicate groundwaters supposed to be controlled by kaolinite dissolution/precipitation, and circles indicate groundwaters with high DOC.

explanation was found for the fact that the point S5-380 is far away from equilibrium due to the very low $\mathrm{Al}$ concentrations that have always been observed along the three sampling periods, although these low values are consistent with the gradual decrease of $\mathrm{Al}$ concentration in the groundwater along the slope. The channel bottom groundwater (SCB-15) is clearly oversaturated with regard to kaolinite because of very high Si concentrations likely due, as stressed before, to litter mineralization.

\subsubsection{Iron, iron-bearing minerals and bleaching of the kaolin}

Iron in the soil system is mainly transported as $\mathrm{Fe}^{2+}$ even when $E_{\mathrm{H}}$ is relatively high, more than $450 \mathrm{mV}$. As seen in the Fe Pourbaix diagram (Fig. 8), the DOM-rich groundwaters from the white sands or the channel bottom (circles) are well below the $\mathrm{Fe}^{2+} / \mathrm{Fe}^{3+}$ transition, which is explained by acidity for the white-sand groundwater and by lower $E_{\mathrm{H}}$ for the channel bottom (SCB-15) where litter mineralization occurs. Except for the S2-160 point, all DOM-poor groundwaters circulating in the kaolin as well as in the Ef horizons are close to the $\mathrm{Fe}^{2+} / \mathrm{Fe}^{3+}$ transition, most of the time slightly below, indicating that the mobility of iron in these horizons depends on small $E_{\mathrm{H}}$ variations which can be due to microbial pulses in upper horizons or in Bh-Bhs (Montes et al., 2007). According to Cornell and Schwertmann (2003), the bright orange-colored coatings in tubular pores observed immediately beneath the Bhs are characteristics of lepidocrocite, which forms by fast iron precipitation in soils submitted to rapid $E_{\mathrm{H}}$ changes. The position of the S2-160 point (Ef horizon) is characterized by a low $E_{\mathrm{H}}$ when compared to the upstream S1-240 or W2-150 points or the downstream S3-160 point. This may be due to the fact that the water sampled at this point has just flowed through the Bh-Bhs, where organic

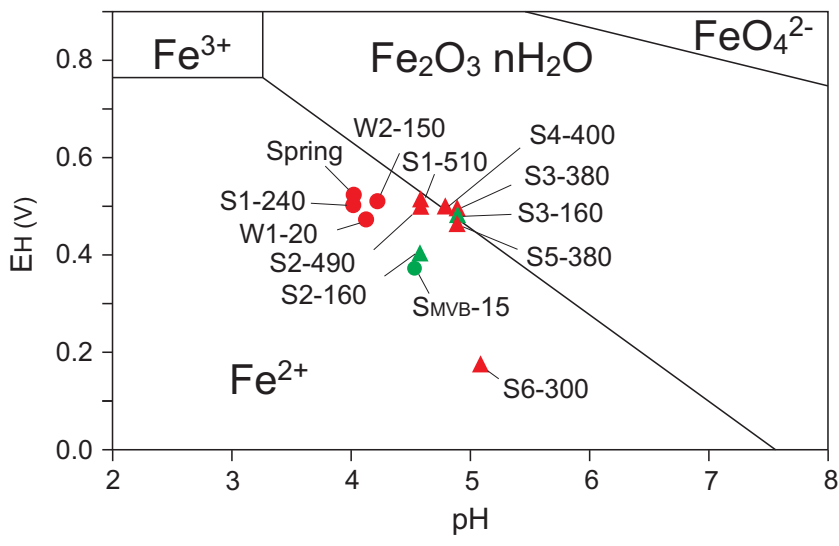

Fig. 8. Position of the groundwaters in the iron Pourbaix diagram drawn for low Fe-concentrated waters $\left(<10^{6} \mathrm{M}\right)$. Symbols are the same as in Fig. 7.

matter oxidation may lower the $E_{\mathrm{H}}$. Downslope, sulphidesmelling groundwaters of point S6-300 are typical of reduced conditions.

Two processes are thus able to favor the bleaching of the kaolin associated with podzol areas. The first one, as hypothesized by Montes et al. (2007), is that solutions percolating at depth are able to reduce iron and that their reducing capacity can be enhanced by mineralization in depth of the organic matter transferred from the topsoil by podzolic processes. The second one is that small carboxylic compounds transferred from the podzolic horizons are able to migrate within the kaolin, enhancing the iron mobility by complexing $\mathrm{Fe}^{3+}$ and, as already observed in very oxidizing media (Kieber et al., 2005), $\mathrm{Fe}^{2+}$. This latter process can also explain the lack of a good correlation between $E_{\mathrm{H}}$ and $\mathrm{Fe}^{2+}$. The final result is a complete bleaching of kaolin horizons, and it is likely that the deeper the permanent water table, the deeper the percolation of the groundwater and the thicker the kaolin bleached horizons are.

\subsection{Concluding remarks}

We studied the groundwater composition of a typical Amazonian podzol-ferralsol soil system in order to assess the specific role of DOM on NOM storage in deep horizons and to determine possible relationships between kaolin formation and DOM properties.

The groundwater produced by the hydromorphic podzols is acidic and DOM-rich. This DOM has a high proportion of humic compounds and less than $10 \%$ of small carboxylic acids; its acid-site density and properties are similar to those observed in podzolic temperate areas. Part of this DOM is directly exported to the blackwater streams by overflowing in the lower parts of the podzolic areas and through a specific network of U-shaped channels at the podzol-ferralsol transition. Another part percolates at greater depth, down to the 
kaolin or ferralsolic horizons, and more than $90 \%$ of it adsorbs in the Bhs horizons, allowing carbon storage at depth. It is likely that part of the adsorbed OM can suffer posterior mineralization; the rate of such a process, which determines the rate of carbon storage, has yet to be defined. When passing the Bhs, humic substances are preferentially adsorbed with regard to small carboxylic acids, so that the groundwater that percolates in the kaolin is DOM-poor with a high proportion of small carboxylic acids and therefore a high acid-site density.

With regard to kaolin genesis, kaolinite precipitation, and subsequent quartz dissolution, is favored by $\mathrm{Al}$ release from NOM mineralization within the $\mathrm{Bh}$, and kaolin bleaching is ensured by iron reduction due to acidity and relatively low $E_{\mathrm{H}}$. $\mathrm{Fe}^{2+}$ mobility can be related to small $E_{\mathrm{H}}$ variations, for which microbial activity in the Bhs can be decisive, and enhanced by the significant concentration of small carboxylic acids. The long-term result of these processes is the thickening of the kaolin, and it can be inferred that kaolin is likely to occur where active, giant podzols are close to a slope gradient sufficient enough to lower the deep water table, which is a configuration easily identified by remote sensing.

\section{Supplementary material related to this article is available online at: http://www.biogeosciences.net/9/ 3705/2012/bg-9-3705-2012-supplement.pdf.}

Acknowledgements. This work benefited from FAPESP funding No. 07/02543-0, from ARCUS PACA-Brésil funding (French Ministry of Foreign Affairs and Région Provence-Alpes-Côte d'Azur) and from CAPES-COFECUB bilateral cooperation funding. We thank K. Gibbon-Walsh for correction of English.

Edited by: R. Conant

\section{References}

Ball, J. W. and Nordstrom, D. K.: User's manual for Wateq4F, with revised thermodynamic data base and test cases for calculating speciation of major, trace, and redox in natural waters, US Geol. Survey Open File Rep., 91-183, 1991.

Bardy, M., Fritsch, E., Derenne, S., Allard, T., do Nascimento, N. R., and Bueno, G. T.: Micromorphology and spectroscopic characteristics of organic matter in waterlogged podzols of the upper Amazon basin, Geoderma, 145, 222-230, 2008.

Batjes, N. H. and Dijkshoorn, J. A.: Carbon and nitrogen stocks in the soils of the Amazon Region, Geoderma, 89, 273-286, 1999.

Benedetti, M. F., Ranville, J. F., Allard, T., Bednar, A. J., and Menguy, N.: The iron status in colloidal matter from the Rio Negro, Brasil. Coll. Surf. A., 217, 1-9, 2003.
Bernoux, M., Carvalho, M. C. S., Volkoff, B., and Cerri, C. C.: Brazil's soil carbon stocks, Soil Sci. Soc. Am. J., 66, 888-896, 2002.

Boulet, R., Chauvel, A., Humbel, F. X., and Lucas, Y.: Analyse structurale et cartographie en pédologie. I-Prise en compte de l'organisation bidimensionnelle de la couverture pédologique: les études de toposéquences et leurs principaux apports à la connaissance des sols, Cah. ORSTOM, sér. Pédol. XIX, 4, 309-321, 1982.

Bravard, S. and Righi, D.: Characterization of fulvic and humic acids from an Oxisol-Spodosol toposequence of Amazonia, Brazil, Geoderma, 48, 151-162, 1991.

Chauvel, A., Lucas, Y., and Boulet, R.: On the genesis of the soil mantle of the region of Manaus, Central Amazonia, Brazil, Experientia, 43, 234-241, 1987.

Chauvel, A., Walker, I., and Lucas, Y.: Sedimentation and pedogenesis in a Central Amazonian Black water basin, Biogeochemistry, 33, 77-95, 1996.

Chin, T. P., Aiken, G., O'Loughlin, E.: Molecular weight, polydispersity, and spectroscopic properties of aquatic humic substances, Environ. Sci. Technol., 28, 1853-1858, 1994.

Cornell, R. M. and Schwertmann, U.: The Iron Oxides: Structure, Properties, Reactions and Uses, VCH, Weinheim, Freising, Germany, p. 355, 2003.

Cornu, S., Ambrosi, J. P., Lucas, Y., and Février, D.: A comparative study of the soil solution chemistry of two Amazonian forest soils (Central Amazonia, Brazil), Hydrol. Earth Syst. Sc., 1, 313324, 1997.

Cornu, S., Lucas, Y., Ambrosi, J. P., and Desjardins, T.: Transfer of dissolved $\mathrm{Al}, \mathrm{Fe}$ and $\mathrm{Si}$ in two amazonian forest environment in Brazil, Eur. J. Soil Sci., 49, 377-384, 1998.

Costa, M. L. and Moraes, E. L.: Mineralogy, geochemistry and genesis of kaolin from the Amazon region, Mineralium Deposita, 33, 283-297, 1998.

Cuss, C. W., Guéguen, C., Hill, E., and Dillon, P. J.: Spatio-temporal variation in the characteristics of dissolved organic matter in the streams of boreal forests: Impacts on modelled copper speciation, Chemosphere, 80, 764-770, 2010.

Dall'Agnol, R. and Macambira, M. J. B.: Titanita-biotita granitos do baixo Rio Uaupés, Província Rio Negro, Amazonas. Parte 1: Geologia, petrografia e geocronologia, Rev. Bras. Geocienc., 22, 3-14, 1992.

Davis, J. A.: Adsorption of natural dissolved organic matter at the oxide/water interface, Geochim. Cosmochim. Ac., 46, 23812393, 1982.

Delarue, F., Cornu, S., Daroussin, J., Salvador-Blanes, S., Bourennane, H., Albéric, P., Vennink, A., Bruand, A., and King, D.: 3D representation of soil distribution: An approach for understanding pedogenesis, C. R. Geosci., 341, 486-494, 2009.

Dubroeucq, D. and Volkoff, B.: From oxisols to spodosols and histosols: evolution of the soil mantles in the Rio Negro Basin (Amazonia), Catena, 32, 245-280, 1998.

FAO: World Soil Resources, An explanatory note on the FAO World Soil Resources Map at 1:25000 000 scale, World Soil Resources Report 66, Rev. 1, Rome, FAO, 1993.

Fritsch, E., Allard, T., Benedetti, M. F., Bardy, M., do Nascimento, N. R., Li, Y., and Calas, G.: Organic complexation and translocation of ferric iron in podzols of the Negro River watershed. Separation of secondary Fe species from Al species, Geoch. Cos- 
moch. Ac., 73, 1813-1825, 2009.

Garnier, C., Mounier, S., and Benaim, J. Y.: Influence of dissolved organic carbon content on modelling natural organic matter acidbase properties, Water Res., 38, 3685-3692, 2004a.

Garnier, C., Pizeta, I., Mounier, S., Benaim, J. Y., and Branica, M.: The influence of the type of titration and of data treatment method on metal complexing parameters determination of single and multi ligand systems measured by stripping voltammetry, Anal. Chim. Acta, 505, 263-275, 2004b.

Grimaldi, C., Grimaldi, M., Millet, A., Bariac, T., and Boulègue, J.: Behaviour of chemical solutes during a storm in a rainforested headwater catchment, Hydrol. Process., 18, 93-106, 2004

Hruska, J., Köhler, S., Laudon, H., and Bishop, K.: Is a universal model of organic acidity possible: comparison of the acid/base properties of dissolved organic carbon in the boreal and temperate zones, Environ. Sci. Technol., 37, 1726-1730, 2003.

IBGE: Levantamento pedológico, folhas NA-19, NA-20, SA-19 e SA-20, available at:http://www.ibge.gov.br/home/geociencias/ download/arquivos/index9.shtm, last access: 27 September 2012, CREN-IBGE, São Paulo, 2009.

Ishida, D. A.: Caracterização e gênese de solos e de depósito de caulim associado, São Gabriel da Cachoeira - AM, Thesis, Universidade de São Paulo, 172 pp., 2010.

Kaiser, K. and Zech, W.: Dissolved organic matter sorption by mineral constituents of subsoil clay fractions, J. Plant Nutr. Soil Sc., $163,531-535,2000$.

Kang, S. and Xing, B.: Adsorption of dicarboxylic acids by clay minerals as examined by in situ ATR-FTIR and ex situ DRIFT, Langmuir, 23, 7024-7031, 2007.

Kieber, R. J., Skrabal, S. A., Smith, B. J., and Willey, J. D.: Organic Complexation of Fe(II) and Its Impact on the Redox Cycling of Iron in Rain, Environ. Sci. Technol., 39, 1576-1583, 2005.

Köhler, S., Hruska, J., and Bishop, K.: Influence of organic acid site density on $\mathrm{pH}$ modeling of Swedish lakes, Can. J. Fish Aquat. Sci., 56, 1461-1470, 1999.

Leenheer, J. A.: Origin and nature of the humic substances in the waters of the Amazon River basin, Acta Amazonica, 10, 513526, 1980.

Lucas, Y.: The role of the plants in controlling rates and products of weathering: importance of the biological pumping, Ann. Rev. Earth Pl. Sc., 29, 135-163, 2001.

Lucas, Y., Chauvel, A., Boulet, R., Ranzani, G., and Scatolini, F.: Transiçâo latossolos-podzois sobre a formaçâo Barreias na regiâo de Manaus, Amazônia, Rev. Bras. Cienc. Solo, 8, 325335,1984

Lucas, Y., Boulet, R., and Chauvel, A.: Intervention simultanée des phénomènes d'enfoncement vertical et de transformation latérale dans la mise en place de systèmes de sols de la zone tropicale humide. Cas des systèmes sols ferrallitiques - podzols de l'Amazonie Brésilienne, CR. Acad. Sci. II A, 306, 1395-1400, 1988.

Lucas, Y., Luizão, F. J., Chauvel, A., Rouiller, J., and Nahon, D.: The relation between biological activity of the rainforest and mineral composition of the soils, Science, 260, 521-523, 1993.

Lucas, Y., Nahon, D., Cornu, S., and Eyrolle, F.: Genèse et fonctionnement des sols en milieu équatorial, CR. Acad. Sci. II A, 322, 1-16, 1996.

Lundström, U. S., van Breemen, N., and Bain, D.: The podzolisation process, a review, Geoderma, 94, 91-107, 2000.
McClain, M. E., Richey, J. E., Brandes, J. A., Pimentel, T. P.: Dissolved organic matter and terrestrial-lotic linkages in the Central Amazon Basin of Brazil, Global Biogeochem. Cy., 11, 295-311, 1997.

Menzies, N. W., Kerven, G. L., Bell, L. C., and Edwards, D. G.: Determination of total soluble aluminum in soil solution using pyrocatechol violet, lanthanum and iron to discriminate against micro-particulates and organic ligands, Com. Soil Sci. Plant Anal., 23, 2525-2545, 1992.

Montes, C. R., Lucas, Y., Melfi, A. J., and Ishida, D. A.: Systèmes sols ferrallitiques-podzols et genèse des kaolins, C. R. Geosci., 339, 50-56, 2007.

Montes, C. R., Lucas, Y., Pereira, O. J. R., Achard, R., Grimaldi, M., and Melfi, A. J.: Deep plant-derived carbon storage in Amazonian podzols, Biogeosciences, 8, 113-120, doi:10.5194/bg-8113-2011, 2011.

Munsell: Munsell soil color chart, Kollmorgen Instruments Corp., New York, 1990.

Nascimento, N. R., Bueno, G. T., Fritsch, E., Herbillon, A. J., Allard, T., Melfi, A., Astolfo, R., Boucher, H., and Li, Y.: Podzolization as a deferralitization process: a study of an AcrisolPodzol sequence derived from Palaeozoic sandstones in the northern upper Amazon Basin, Eur. J. Soil Sci., 55, 523-538, 2004.

Nascimento, N. R., Fritsch, E., Bueno, G. T., Bardy, M., Grimaldi, C., and Melfi, A.: Podzolization as a deferralitization process: dynamics and chemistry of ground and surface waters in an Acrisol - Podzol sequence of the upper Amazon Basin, Eur. J. Soil Sci., 59, 911-924, 2008.

Patel-Sorrentino, N., Mounier, S., Lucas, Y., and Benaim, J. Y.: Effect of UV-Visible irradiation on natural orgaic matter from the Amazon basin, Sci. Total Environ., 321, 231-239, 2004.

Patel-Sorrentino, N., Lucas, Y., Eyrolles, F., and Melfi, A. J.: Fe, $\mathrm{Al}$ and Si species and organic matter leached off a ferrallitic and podzolic soil system from Central Amazonia, Geoderma, 137, 444-454, 2007.

Prance, G. T.: The origin and evolution of the Amazon flora, lnterciencia, 3, 207-222, 1978.

RadamBrasil: Levantamento de Recursos Naturais, Ministério de Minas e Energia, Departamento Nacional de Produção Mineral, Rio de Janeiro, 1978.

Ravichandran, M., Aiken, G. R., Reddy, M. M., and Ryan, J. N.: Enhanced Dissolution of Cinnabar (Mercuric Sulfide) by Dissolved Organic Matter Isolated from the Florida Everglades, Env. Sci. Technol., 32, 3305-3311, 1998.

Robert, M. and Berthelin, J.: Role of biological and biochemical factors in soil mineral weathering, in: Interactions of soil minerals with natural organics and microbes, edited by: Huang, P. M. and Schnitzer, M., SSSA Special Publication No. 17, Madison, 453-495, 1986.

Schwartz, J., Kowalczuk, P., Kaczmarek, S., Cota, G. F., Mitchell, G., Kahru, M., Chavez, F. P., Cunningham, A., McKee, D., Gege, P., Kishino, M., Phinney, D. A., and Raine, R.: Two models for adsorption by coloured dissolved organic matter (CDOM), Oceanologia, 44, 209-241, 2002.

Tardy, Y. and Nahon, D.: Geochemistry of laterites, stability of Algoethite, Al-hematite, and $\mathrm{Fe} 3+$ kaolinites in bauxites and ferricretes: an approach to the mechanism of concretion formation, Am. J. Sci., 285, 865-903, 1985. 
Tardy, Y., Roquin, C., Bustillo, V., Moreira, M., Martinelli, L. A., and Victoria, R.: Carbon and Water Cycles, Amazon River Basin. Applied Biogeochemistry, Atlantica, Biarritz, 400-402, 2009.

Veillon, L. and Soria-Solano, B.: Transition sol ferrallitique-podzol: cas d'une terrasse sédimentaire de l'Ucayali (Perou), Cah. ORSTOM, sér. Pédol., 24, 97-113, 1988.
Zanchi, F. B., Waterloo, M. J., Dolman, A. J., Groenendijk, M., Kesselmeier, J., Kruijt, B., Bolson, M. A., Luizao, F. J., and Manzi, A. O.: Influence of drainage status on soil and water chemistry, litter decomposition and soil respiration in central Amazonian forests on sandy soils, Ambiente \& Água, 6, 6-29, 2011. 